\title{
Contexto geológico e litogeoquímica das unidades plutônicas-vulcânicas da região de União do Norte, setor leste da Província Aurífera de Alta Floresta (MT)
}

\author{
Rafael Rodrigues de Assis ${ }^{1}$, Roberto Perez Xavier², Antônio João Paes de Barros ${ }^{3}$, \\ Danilo Barbuena ${ }^{1}$ \& Emílio Miguel Júnior ${ }^{1}$
}

\begin{abstract}
Resumo A Província Aurífera de Alta Floreta, centro-sul do Craton Amazônico, representa uma unidade tectônica essencialmente composta por sequências plutônicas-vulcânicas geradas em ambiente de arcos magmáticos que se desenvolveram e se agregaram progressivamente no decorrer do Paleoproterozoico. No segmento leste desta província, na região de União do Norte (Peixoto de Azevedo, MT), rochas plutônicas e vulcânicas são as hospedeiras de depósitos auríferos com sulfetos de metais de base (esfalerita+galena \pm di genita \pm calcopirita), alguns atualmente em explotação por garimpeiros. O arcabouço geológico desta região consiste de uma unidade vulcanoclástica de origem epiclástica que aloja várias suítes graníticas. Na unidade vulcanoclástica predominam grauvaca-feldspática e arenito arcoseano lítico vulcanoclásticos, possivelmente depositados em bacia de retroarco do tipo foreland, em margem ativa, cuja área fonte teriam sido vulcânicas intermediárias. As suítes intrusivas são representadas por plútons que variam em composição de (1) granodiorito, (2) sieno-monzogranito a, (3) álcali-feldspato granito porfirítico e monzogranito porfirítico (Pórfiro União do Norte). Todas essas unidades são ainda cortadas por diques de vulcânicas máficas a félsicas. No conjunto, essas unidades são recobertas pelos sedimentos arenáceos da Formação Dardanelos. Dados geoquímicos obtidos para as unidades plutônicas-vulcânicas indicam magmatismo eminentemente cálcio-alcalino de alto $\mathrm{K}$, magnesiano, metaluminoso e subordinadamente alcalino, peraluminoso e ferroso. Evidências de campo em conjunto com os dados litogeoquímicos indicam que as séries magmáticas representam a evolução do ambiente tectono-magmático, desde a geração de rochas mais primitivas em ambiente de arco vulcânico (granodiorito; granito tipo I) até o alojamento de corpos altamente evoluídos (Pórfiro União do Norte; granito tipo A) em arcabouço pós-colisional.
\end{abstract}

Palavras-chave: Província Aurífera de Alta Floresta, granitos tipo I e A, petrografia, geoquímica.

\begin{abstract}
Geological setting and geochemistry of the plutonic-volcanic units from the União do Norte region, eastern portion of the Alta Floresta Gold Province (MT). The Alta Floresta Gold Province, eastern portion of the Amazon Craton, represents a tectonic unit composed primarily of plutonic-volcanic sequences generated in a continental arc during the Paleoproterozoic. Particularly in the União do Norte region, easternmost segment of this province and within the municipal limits of Peixoto de Azevedo (MT), the plutonic and volcanic rocks are the host of gold deposits with base metal sulphides (sphalerite + galena \pm chalcopyrite \pm digenite), some currently under exploitation by local prospectors (garimpeiros). The geological setting of this region consists essentially of an epiclastic volcaniclastic unit and granitic suites. The former unit contains feldspathic-arenite and feldspathic-wake volcaniclastics interpreted to have been deposited in a retroarc foreland basin in an active continental margin. The main source area for these sediments would have been intermediate volcanic rocks. The granitoids show composition ranging from granodiorite to alkali-feldspar porphyritic granite (União do Norte Porphyry). Mafic to felsic volcanic dikes crosscut both the volcaniclastic unit as the granitoids, which are still overlain by arenaceous sediments of the Dardanelos Formation. The plutonic and volcanic units represent essentially a high-K calc-alkaline, magnesium to ferrous, metaluminous to subordinate alkaline and peraluminous magmatism. Additionally, field and geochemical data also indicate that the granitic suites represent a magmatic series that probably evolved from granodiorites (I-type granite) generated in the onset of a volcanic arc to the emplacement of highly-evolved granitic rocks, such as the União do Norte Porphyry (A-type granite), in a post-collisional setting.
\end{abstract}

Keywords: Alta Floresta Gold Province, I-A-type granites, petrography, geochemistry.

\footnotetext{
1 - Programa de Pós-graduação em Geociências da Universidade Estadual de Campinas, Campinas (SP), Brasil. E-mail: rafael.assis@ige.unicamp.br, danilobarbuena@hotmail.com,emiliogel@yahoo.com.br

2 - Universidade Estadual de Campinas, Departamento de Geologia e Recursos Minerais, Campinas (SP), Brasil. E-mail: xavier@ige.unicamp.br

3 - Companhia Matogrossense de Mineração, Cuiabá (MT). E-mail: ajpbarros@uol.com.br
} 
INTRODUÇÃO A Província Aurífera de Alta Floresta (PAAF) localiza-se na porção centro-sul do Cráton Amazônico, norte do estado do Mato Grosso. Configura uma área alongada de direção noroeste-sudeste, limitada a norte pelo Gráben do Cachimbo, que a separa da Província Aurífera do Tapajós, e a sul pelo gráben dos Caiabis. A depender do modelo adotado é considerada como parte de diferentes províncias geocronológicas, cujos limites temporais e espaciais diferem na compartimentação geotectônica do Cráton Amazônico. Nesse sentido, insere-se nas Províncias Ventuari-Tapajós (1,95-1,8 Ga) e Rio Negro-Juruena (1,8-1,55 Ga), na concepção de Tassinari \& Macambira (1999), ou nas Províncias Tapajós-Parima (2,03-1,88 Ga) e Rondônia-Juruena (1,82-1,54 Ga) no modelo de Santos et al. (2001). Independente do modelo adotado, dados geológicos, geoquímicos e isotópicos indicam que as unidades plutônicas-vulcânicas que compõem essas províncias foram geradas em ambiente de arcos magmáticos que se desenvolveram e se agregaram progressivamente ao protocráton formado pela Província Amazônia Central no decorrer do Paleoproterozoico (Riaciano a Estateriano) (Tassinari \& Macambira 1999, Santos 2006, Silva \& Abram 2008).

No período de 1980-1989, a PAAF tornou-se uma das principais regiões auríferas do país, com uma produção de $\mathrm{Au}$ estimada em 160 t (Paes de Barros 2007), proveniente essencialmente de atividade garimpeira. Uma grande parcela dos depósitos auríferos, geralmente de pequeno porte $(<5 \mathrm{t})$, concentra-se no setor leste da província ao longo de um cinturão de direção NW, particularmente na região que abrange os municípios de Nova Santa Helena-Peixoto de Azevedo-Matupá-Guarantã do Norte-Novo Mundo (Paes de Barros 2007). Na sua maioria, esses depósitos estão hospedados em granitoides paleoproterozoicos do tipo I, subalcalinos a cálcio-alcalinos, metaluminosos a levemente peraluminosos, de médio a alto potássico, variando em composição de tonalito-granodiorito a sienogranito-monzonito, com forte componente de fonte crustal e arqueana (Paes de Barros 2007, Assis 2008). O ouro nesses depósitos está normalmente associado ao $\mathrm{Cu}$, As, Bi e Te em paragênese dominada por pirita e concentrações variadas de calcopirita.

Em contraste com esses depósitos, também há mineralizações auríferas nesse setor da província associadas a concentrações significativas de Zn (esfalerita) e $\mathrm{Pb}$ (galena). Esses depósitos (e.g. Francisco e Bigode) ocorrem principalmente na região sudeste do município de Peixoto de Azevedo, em domínios da região da Vila de União do Norte (Fig. 1). Apesar dos poucos trabalhos regionais que englobam essa província de comprovado potencial aurífero (Moreton \& Martins 2005, Souza et al. 2005, Paes de Barros 2007, Assis 2008, Assis 2011), os seus arcabouços geológico e geotectônico não se encontram suficientemente esclarecidos. Dessa forma, a meta deste trabalho é definir os contextos geológico e geotectônico da região de União do Norte por meio da caracterização petrográfica e litogeoquímica de suas unidades litodêmicas, o que servirá de substrato para a melhor compreensão da metalogênese aurífera nesse setor da PAAF.

\section{CONTEXTO GEOLÓGICO DO SETOR LESTE} DA PAAF (MT) A PAAF também tem sido denominada de Província Aurífera Juruena-Teles Pires (Silva \& Abram 2008), Domínio Alta Floresta (Santos et al. 2001), ou Província Mineral de Alta Floresta (Souza et al. 2005). Os autores nesse trabalho, no entanto, preferem a denominação de Souza et al. (2005), apenas especificando o fato de corresponder a uma província eminentemente aurífera.

O setor leste da PAAF compreende cinco unidades plutônicas-vulcânicas de idade Paleoproterozoica (Orosiriano-Estateriano), além de uma unidade sedimentar clástica provavelmente Mesoproterozoica, denominada de Grupo Caiabis (Fig. 2). Essas unidades são regionalmente representadas pelo Granito Nhandu (1889-1879 Ma), Suíte Intrusiva Matupá (1872 Ma), Suíte Intrusiva Flor da Serra (idade indeterminada), Suíte Colíder (1786-1781 Ma) e Suíte Intrusiva Teles Pires (1757 Ma) (Santos 2000, Souza et al. 2005, Moreton \& Martins 2005, Silva \& Abram 2008).

Magnetita-biotita monzogranito e sienogranito de afinidade cálcio-alcalina, com enclaves de diorito a quartzo-monzodiorito, além de granitos subvulcânicos subordinados, quartzo sienito finos e granófiricos, compõem o granito Nhandu (Moreton \& Martins 2005, Souza et al. 2005). São rochas que frequentemente hospedam mineralizações auríferas (e.g. Natal, Trairão) e comumente mostram evidências de alteração potássica com microclínio, acompanhada da precipitação de sulfetos e magnetita hidrotermal. A idade do granito Nhan$\mathrm{du}$ foi estabelecida entre $1889 \pm 17$ Ma a $1879 \pm 5,5$ $\mathrm{Ma}$ (U-Pb em zircão), com idades modelo entre 2,14 e $2,17 \mathrm{Ga}$, e $\varepsilon_{\mathrm{Nd}(t)}$ de $-0,91$, sendo seu ambiente tectônico interpretado como pós-colisional a intraplaca (Silva \& Abram 2008). Em adicional, JICA/MMAJ (2000) obteve idades de $1848 \pm 17$ Ma para essa suíte.

A Suíte Intrusiva Matupá é constituída por quatro litofácies que incluem biotita granito e biotita monzogranito porfiríticos (fácies 1); hornblenda monzogranito, biotita-hornblenda monzonito e hornblenda monzodiorito (fácies 2); clinopiroxênio-hornblenda monzogranito e clinopiroxênio-hornblenda monzodiorito (fácies 3); e granito, biotita granito e monzogranito com microgranito e granófiros subordinados (fácies 4) (Moura 1998, Moreton \& Martins 2005). As 


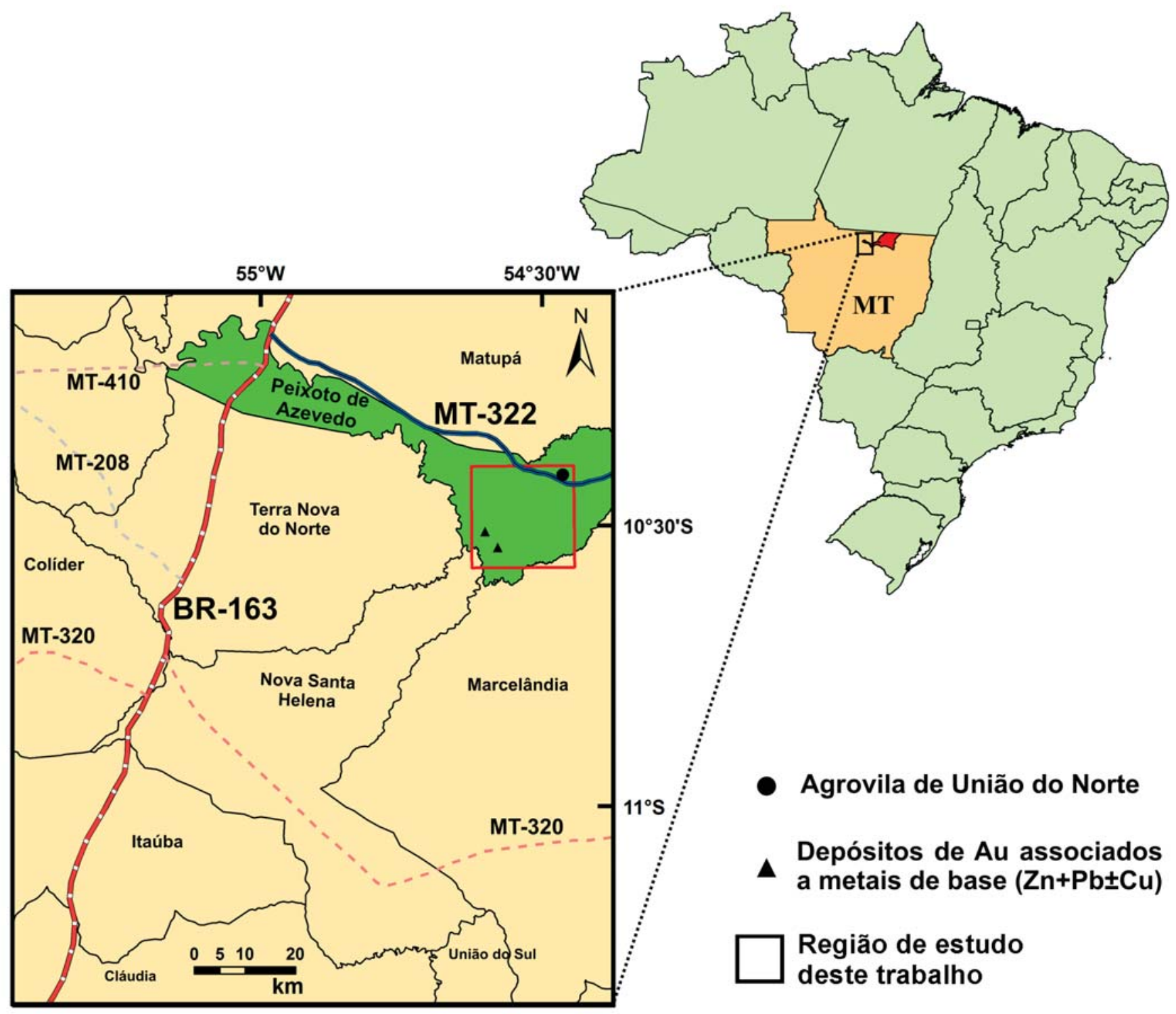

Figura 1 - Mapa de localização da região de União do Norte e dos principais depósitos de ouro associado a metais de base $(\mathrm{Zn}+\mathrm{Pb} \pm \mathrm{Cu})$ na região de União do Norte, município de Peixoto de Azevedo.

fácies 1 e 2 hospedam mineralizações auríferas, sendo o Depósito Serrinha o exemplo melhor investigado (Moura et al. 2006). Uma idade $\mathrm{Pb}-\mathrm{Pb}$ em zircão de $1872 \pm 12$ Ma foi obtida em rochas da fácies 1, além de idades modelo $\left(\mathrm{T}_{\mathrm{DM}}\right)$ que variam no intervalo 2,34 $2,47 \mathrm{Ga}$, e $\varepsilon_{\mathrm{Nd}(t)}$ variando de $-2,7$ a $-4,3$ (Moura, 1998). Idades modelo $\mathrm{T}_{\mathrm{DM}}$ similares $(2,15-2,34 \mathrm{Ga})$ foram obtidas por Souza et al. (2005), contudo, com valores de $\varepsilon_{\mathrm{Nd}(t)}$ entre $-0,98$ e $+3,04$. A Suíte Intrusiva Matupá é intrudida por gabro, gabrodiorito, diorito, monzogabro, monzodioritos, diabásio e subordinadamente por traquiandesito, representantes da Suíte Intrusiva Flor da Serra (Souza et al. 2005) que, segundo Moura \& Botelho (1992) e Silva \& Abram (2008), apresentam características geoquímicas de toleítos continentais intraplaca. Na ausência de dados geocronológicos, Souza et al. (2005) utilizaram uma idade modelo $\mathrm{T}_{\mathrm{DM}}$ de 2,33 Ga (em gabro), do valor de $\varepsilon_{\mathrm{Nd}(\mathrm{t})}$ de $-2,08 \mathrm{e}$ do conjunto de litotipos que compõem essa suíte para correlacioná-la à Suíte Ingarana (Província Aurífera do Tapajós), de idades $1887 \pm 3 \mathrm{Ma}(\mathrm{Pb}-\mathrm{Pb}$ em zircão; Vasquez 2000) e $1879 \pm 3 \mathrm{Ma}$ (U-Pb SHRIMP em zircão; Santos 2000). Considerando essa correlação geocronológica com os desvios padrões, as rochas da Suíte Flor da Serra seriam relativamente mais antigas e/ou contemporâneas àquelas da Suíte Matupá. No entanto, relações geológicas relatadas por Moreton \& Martins (2005) indicam que a Suíte Flor da Serra é intrusiva na Suíte Matupá, o que a tornaria mais jovem. Logo, a idade dessa suíte ainda permanece indefinida. 


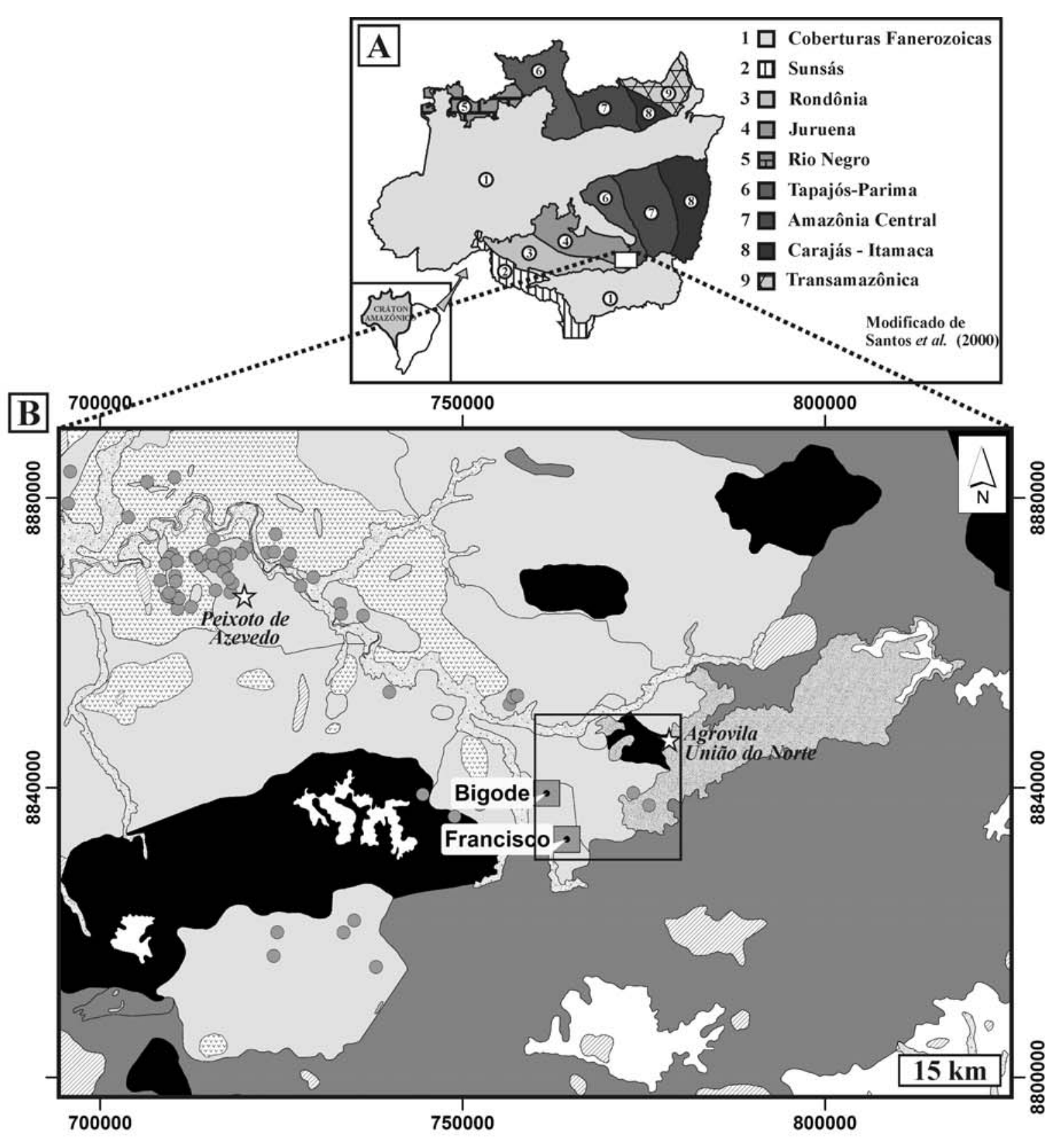

Cenozoico

$\square$ Depósitos Aluvionares

Coberturas

Terciárias-Quaternárias

\section{Mesoproterozoico}

Grupo Caiabis:

Formação Dardanelos

\section{Paleoproterozoico}

$\begin{array}{ll}\square & \text { Suíte Intrusiva Teles Pires } \\ \square \quad \text { Suíte Subvulcânica/Vulcânica Colíder } \\ \square \quad \text { Suíte Intrusiva Flor da Serra } \\ \square \quad \text { Suíte Intrusiva Matupá } \\ \square \quad \text { Suíte Intrusiva Nhandu }\end{array}$

Ocorrências auríferas primárias
Ocorrêncas auriferas associadas a metais de base

\section{Área de estudo}

Figura 2 - (A) Localização da PAAF na compartimentação geotectônica do Cráton Amazônico segundo Santos (2000). (B) Mapa geológico do setor E da PAAF, com destaque na localização das principais ocorrências primárias de ouro (e.g. depósitos do Francisco e do Bigode; extraído de Souza et al. 2005). 
A Suíte Colíder é representada por vulcânicas (derrames e piroclásticas) de composição intermediária a ácida, de alto $\mathrm{K}$, cálcio-alcalina, peraluminosa a metaluminosa, associadas a intrusões epizonais de microgranito, microquartzo monzonito, granófiro, riolito e dacito porfirítico (Moreton \& Martins 2005). Essa suíte mostra contatos tectônicos com as Suítes Matupá e Nhandu, além de possuírem idades U-Pb em zircão de $1781 \pm$ $8 \mathrm{Ma}$ e $1785 \pm 6,3 \mathrm{Ma}$, e idade modelo $\mathrm{T}_{\mathrm{DM}}$ de $2,34 \mathrm{Ga}$ e $\varepsilon_{\mathrm{Nd}(t)}$ de -3,75 (Pimentel 2001, Silva \& Abram 2008).

Intrusivos em todas as unidades anteriores ocorrem batólitos e stocks da Suíte Intrusiva Teles Pires, constituída essencialmente por biotita granitos a álcali-feldspato granitos isotrópicos, de coloração avermelhada, granulação média a grossa, localmente com texturas porfirítica, granofírica, rapakivi e anti-rapakivi (Souza et al. 1979, Silva et al. 1980, Souza et al. 2005). Os dados geoquímicos apontam para granitos do tipo A, de natureza cálcio-alcalina de médio a alto $\mathrm{K}$, metaluminosa a peraluminosa, que correspondem a intrusões pós-colisionais, com idades U-Pb em zircão de $1757 \pm$ $16 \mathrm{Ma}$ a $1782 \pm 17 \mathrm{Ma}$, além de idade modelo $\mathrm{T}_{\mathrm{DM}}$ variando de 1,94 a 2,28 Ga e valores de $\varepsilon_{\mathrm{Nd}(t)}$ de $-3,4 \mathrm{a}+3,0$ (Santos 2000, Pinho et al. 2001, Silva \& Abram 2008).

Recobrindo as unidades plutônicas-vulcânicas, sobretudo a Suíte Colíder, encontram-se sequências de arenitos e arcóseos de granulometria média e frequentes níveis conglomeráticos, pertencentes à Formação Dardanelos (Grupo Caiabis). Essas sequências apresentam estratificações plano-paralelas e cruzadas acanaladas interpretadas como um sistema de leques aluviais de rios entrelaçados, com idade máxima de 1,38 Ga (Leite $\&$ Saes 2003, Souza et al. 2005). O Grupo Caiabis, com deposição associada às principais zonas de transcorrência sinistrais NW/SE, é interpretado como uma bacia do tipo pull-apart, ou possivelmente do tipo strike-slip (Souza et al. 2005).

MATERIAIS E MÉTODOS Com o auxilio de imagens ASTER foi realizado um mapeamento geológico em escala 1:100.000 de uma área de aproximados $400 \mathrm{~km}^{2}$ na região da Vila de União do Norte, com o objetivo de reconhecer as principais unidades litodêmicas e estruturas da região. Esse mapeamento foi posteriormente refinado no entorno do Depósito do Francisco, o que possibilitou a geração de seu mapa geológico em semidetalhe (1:25.0000).

A classificação e descrição petrográficas das unidades individualizadas foi efetuada com o auxílio de 40 lâminas delgadas-polidas. Foram selecionadas 34 amostras representativas das suítes plutônicas-vulcânicas para geoquímica em rocha total. Os diques de vulcânicas totalizaram nove amostras, enquanto que a Suíte Granodiorítica teve oito, o Pórfiro União do Norte com seis, a Suíte Granítica com sete e a Unidade Vulcanoclástica com quatro (Tab. 1). Essas análises foram realizadas pelo Laboratório ACME do Canadá. As concentrações de elementos maiores foram obtidas por ICP-OES após fusão na presença de $\mathrm{LiBO}_{2}$ e posterior digestão em ácido nítrico. Os elementos-traço foram analisados por ICP-MS após fusão em $\mathrm{LiO}_{2}$ e posterior digestão em $\mathrm{HNO}_{3}$.

Tabela 1 - Análises geoquímicas das unidades plutônicas-vulcânicas e vulcanoclástica da região de União do Norte (MT). Os óxidos estão representados na forma de porcentagem, em peso, e os elementos-traço e ETR, em ppm.

\begin{tabular}{ccccccccc}
\hline \multirow{2}{*}{$\begin{array}{c}\text { Emostra/ } \\
\text { Elemento }\end{array}$} & \multicolumn{7}{c}{ Suíte Granodiorítica / Legenda: $\bullet$} \\
\cline { 2 - 9 } & Pto 50 & Ptp 53.B & Pto 77.A & VU-09 & FR-03 & FR-07 & FR-08 & FR-113G \\
\hline $\mathrm{SiO}_{2}$ & 57,94 & 57,37 & 54,33 & 65,79 & 55,07 & 62,32 & 66,15 & 60,5 \\
\hline $\mathrm{Al}_{2} \mathrm{O}_{3}$ & 15,83 & 16,29 & 16,49 & 15,56 & 19,04 & 14,43 & 15,65 & 14,48 \\
\hline $\mathrm{Fe}_{2} \mathrm{O}_{3}$ & 6,94 & 6,86 & 7,41 & 4,44 & 6,16 & 5,42 & 3,85 & 5,98 \\
\hline $\mathrm{MgO}$ & 3,15 & 3,27 & 3,78 & 1,3 & 2,39 & 3,12 & 1,49 & 3,41 \\
\hline $\mathrm{CaO}$ & 4,43 & 5,44 & 6,89 & 3,74 & 7,32 & 4,28 & 3,71 & 4,72 \\
\hline $\mathrm{Na}_{2} \mathrm{O}$ & 3,73 & 4,14 & 4,04 & 3,61 & 3,49 & 3,3 & 3,81 & 3,3 \\
\hline $\mathrm{K}_{2} \mathrm{O}$ & 3,92 & 3,1 & 2,86 & 2,87 & 2,11 & 4,01 & 2,7 & 3,79 \\
\hline $\mathrm{TiO}_{2}$ & 0,86 & 0,85 & 0,86 & 0,51 & 0,74 & 0,72 & 0,49 & 0,81 \\
\hline $\mathrm{P}_{2} \mathrm{O}_{5}$ & 0,36 & 0,36 & 0,32 & 0,17 & 0,31 & 0,25 & 0,15 & 0,28 \\
\hline $\mathrm{MnO}_{\mathrm{Cr}} \mathrm{O}_{3}$ & 0,12 & 0,11 & 0,23 & 0,05 & 0,12 & 0,1 & 0,08 & 0,11 \\
\hline $\mathrm{LOI}_{\mathrm{Mo}}$ & 0,006 & 0,008 & 0,009 & 0,004 & 0,004 & 0,016 & 0,006 & 0,018 \\
\hline & 2,2 & 1,8 & 2,4 & 1,7 & 3 & 1,7 & 1,7 & 2,3 \\
\hline & 1,4 & 1 & 1,2 & 1,2 & 0,8 & 2 & 0,3 & 0,4 \\
\hline
\end{tabular}


Tabela 1 - Continuação.

\begin{tabular}{|c|c|c|c|c|c|c|c|c|}
\hline \multirow{2}{*}{$\begin{array}{l}\text { Amostra/ } \\
\text { Elemento }\end{array}$} & \multicolumn{8}{|c|}{ Suíte Granodiorítica / Legenda: $\triangle$} \\
\hline & Pto 50 & Ptp 53.B & Pto 77.A & VU-09 & FR-03 & FR-07 & FR-08 & FR-113G \\
\hline $\mathrm{Cu}$ & 81,1 & 59,4 & 48,3 & 7,2 & 11,2 & 60,3 & 7,3 & 68,8 \\
\hline $\mathrm{Pb}$ & 151,2 & 19,6 & 99,6 & 8,7 & 12,7 & 23,9 & 6,6 & 30,3 \\
\hline $\mathrm{Zn}$ & 114 & 46 & 60 & 58 & 66 & 47 & 42 & 40 \\
\hline $\mathrm{Ni}$ & 19,6 & 21,5 & 36,1 & 4,6 & 4,8 & 23,9 & 3,6 & 22,3 \\
\hline As & 2,5 & 1,2 & 0,7 & 0,7 & 0,5 & $<0,5$ & 0,6 & $<0,5$ \\
\hline $\mathrm{Cd}$ & 0,3 & $<0,1$ & $<0,1$ & $<0,1$ & $<0,1$ & $<0,1$ & $<0,1$ & $<0,1$ \\
\hline $\mathrm{Sb}$ & $<0,1$ & $<0,1$ & $<0,1$ & $<0,1$ & $<0,1$ & $<0,1$ & $<0,1$ & $<0,1$ \\
\hline $\mathrm{Bi}$ & $<0,1$ & $<0,1$ & $<0,1$ & $<0,1$ & $<0,1$ & 0,1 & $<0,1$ & $<0,1$ \\
\hline $\mathrm{Ag}$ & 0,1 & $<0,1$ & $<0,1$ & $<0,1$ & $<0,1$ & 0,1 & $<0,1$ & $<0,1$ \\
\hline $\mathrm{Au}$ & 25,7 & 5,1 & 1,6 & 0,9 & $<0,5$ & 1,6 & 0,6 & $<0,5$ \\
\hline $\mathrm{Hg}$ & $<0,01$ & $<0,01$ & $<0,01$ & $<0,01$ & $<0,01$ & $<0,01$ & $<0,01$ & $<0,01$ \\
\hline $\mathrm{Tl}$ & $<0,1$ & $<0,1$ & $<0,1$ & $<0,1$ & $<0,1$ & $<0,1$ & $<0,1$ & $<0,1$ \\
\hline $\mathrm{Se}$ & $<0,5$ & $<0,5$ & $<0,5$ & $<0,5$ & $<0,5$ & $<0,5$ & $<0,5$ & $<0,5$ \\
\hline $\mathrm{Sc}$ & 15 & 16 & 19 & 5 & 18 & 12 & 10 & 13 \\
\hline $\mathrm{Ba}$ & 1398 & 1272 & 1361 & 1202 & 774 & 944 & 1091 & 1242 \\
\hline $\mathrm{Be}$ & 2 & 2 & 2 & 1 & 1 & 2 & 3 & 2 \\
\hline Co & 21,4 & 22 & 27,3 & 8,6 & 11,5 & 17,4 & 7,4 & 18,9 \\
\hline Cs & 0,8 & 0,6 & 1,2 & 0,6 & 0,9 & 1,4 & 1,3 & 1,5 \\
\hline $\mathrm{Ga}$ & 19,3 & 18,3 & 20,8 & 20,2 & 20,4 & 17,8 & 18,2 & 18,8 \\
\hline $\mathrm{Hf}$ & 5,7 & 4,6 & 4,7 & 4,4 & 3,9 & 6,3 & 4,6 & 6,9 \\
\hline $\mathrm{Nb}$ & 10,1 & 9,1 & 8,4 & 8,7 & 4,3 & 12,5 & 6,3 & 12 \\
\hline $\mathrm{Rb}$ & 87,4 & 84,4 & 84,7 & 56,4 & 63,4 & 139 & 66 & 129,2 \\
\hline $\mathrm{Sn}$ & 2 & 1 & 2 & 1 & $<1$ & 2 & $<1$ & 2 \\
\hline $\mathrm{Sr}$ & 715,5 & 775,1 & 808,6 & 595 & 818,1 & 473 & 475,8 & 535,8 \\
\hline $\mathrm{Ta}$ & 0,5 & 0,4 & 0,3 & 0,3 & 0,3 & 0,9 & 0,4 & 0,8 \\
\hline $\mathrm{Th}$ & 10,6 & 8,6 & 6,8 & 7,2 & 3,1 & 16,5 & 6,1 & 14 \\
\hline $\mathrm{U}$ & 3,3 & 2,7 & 2,3 & 1,4 & 0,8 & 4,4 & 1,3 & 3 \\
\hline $\mathrm{V}$ & 127 & 126 & 162 & 64 & 83 & 98 & 52 & 118 \\
\hline W & 0,8 & 0,6 & 0,6 & 0,7 & $<0,5$ & 1,5 & $<0,5$ & 0,8 \\
\hline $\mathrm{Zr}$ & 217,6 & 182,5 & 175,8 & 160,7 & 139,3 & 229 & 152,3 & 249,1 \\
\hline $\mathrm{Y}$ & 19,8 & 18,9 & 20,5 & 12,5 & 16,3 & 20,7 & 15,4 & 20,9 \\
\hline $\mathrm{La}$ & 45,1 & 41,2 & 40,1 & 40,9 & 19,6 & 43,7 & 26,9 & 45,6 \\
\hline $\mathrm{Ce}$ & 92,4 & 87,7 & 84 & 76,5 & 40,4 & 91,7 & 53,2 & 96,5 \\
\hline $\operatorname{Pr}$ & 10,82 & 10,93 & 10,56 & 8,81 & 4,93 & 10,67 & 5,93 & 10,9 \\
\hline $\mathrm{Nd}$ & 41,9 & 42,4 & 41,3 & 32,8 & 20,8 & 40,3 & 23,6 & 42 \\
\hline $\mathrm{Sm}$ & 6,45 & 6,69 & 7,04 & 4,74 & 3,82 & 6,68 & 3,82 & 6,96 \\
\hline $\mathrm{Eu}$ & 1,5 & 1,62 & 1,87 & 1,14 & 1,42 & 1,32 & 1,08 & 1,45 \\
\hline $\mathrm{Gd}$ & 5,36 & 5,13 & 5,21 & 3,46 & 3,68 & 4,7 & 3,25 & 5,09 \\
\hline $\mathrm{Tb}$ & 0,68 & 0,7 & 0,74 & 0,49 & 0,56 & 0,72 & 0,52 & 0,77 \\
\hline Dy & 3,55 & 3,48 & 3,9 & 2,48 & 2,87 & 3,57 & 2,7 & 3,64 \\
\hline Ho & 0,63 & 0,61 & 0,7 & 0,44 & 0,59 & 0,66 & 0,57 & 0,72 \\
\hline $\mathrm{Er}$ & 1,73 & 1,75 & 2,03 & 1,24 & 1,66 & 1,88 & 1,54 & 1,98 \\
\hline $\mathrm{Tm}$ & 0,27 & 0,26 & 0,3 & 0,17 & 0,25 & 0,3 & 0,24 & 0,32 \\
\hline $\mathrm{Yb}$ & 1,64 & 1,74 & 1,84 & 1,06 & 1,52 & 1,94 & 1,6 & 1,87 \\
\hline
\end{tabular}


Contexto geológico e litogeoquímica das unidades plutônicas-vulcânicas da região de União do Norte, setor leste da Província Aurífera de Alta Floresta (MT)

Tabela 1 - Continuação.

\begin{tabular}{ccccccccc}
\hline \multirow{2}{*}{$\begin{array}{c}\text { Amostra/ } \\
\text { Elemento }\end{array}$} & \multicolumn{9}{c}{ Suíte Granodionítica / Legenda: $\triangle$} \\
\cline { 2 - 9 } & Pto 50 & Ptp 53.B & Pto 77.A & VU-09 & FR-03 & FR-07 & FR-08 & FR-113G \\
\hline $\mathrm{Lu}$ & 0,25 & 0,25 & 0,28 & 0,16 & 0,21 & 0,28 & 0,24 & 0,28 \\
\hline$\Sigma \mathrm{ETR}$ & 212,28 & 204,46 & 199,87 & 174,39 & 102,31 & 208,42 & 125,19 & 218,08 \\
\hline $\mathrm{Eu} / \mathrm{Eu} *$ & 0,254 & 0,274 & 0,305 & 0,278 & 0,379 & 0,232 & 0,306 & 0,241 \\
\hline $\mathrm{FeOt} /(\mathrm{FeOt}+\mathrm{MgO})$ & 0,6878 & 0,6772 & 0,6622 & 0,7735 & 0,7205 & 0,6347 & 0,7210 & 0,6368 \\
\hline $\mathrm{Na}_{2} \mathrm{O}+\mathrm{K}_{2} \mathrm{O}$ & 7,6500 & 7,2400 & 6,9000 & 6,4800 & 5,6000 & 7,3100 & 6,5100 & 7,0900 \\
\hline $\mathrm{Al}_{2} \mathrm{O}_{3} /\left(\mathrm{Na}_{2} \mathrm{O}+\mathrm{K}_{2} \mathrm{O}\right)$ & 2,0693 & 2,2500 & 2,3899 & 2,4012 & 3,4000 & 1,9740 & 2,4040 & 2,0423 \\
\hline $\mathrm{Al}_{2} \mathrm{O}_{3} /\left(\mathrm{Na}_{2} \mathrm{O}+\mathrm{K}_{2} \mathrm{O}+\mathrm{CaO}\right)$ & 1,3104 & 1,2847 & 1,1958 & 1,5225 & 1,4737 & 1,2450 & 1,5313 & 1,2261 \\
\hline $\mathrm{Na}_{2} \mathrm{O}+\mathrm{K}_{2} \mathrm{O}-\mathrm{CaO}$ & 3,2200 & 1,8000 & 0,0100 & 2,7400 & $-1,7200$ & 3,0300 & 2,8000 & 2,3700 \\
\hline
\end{tabular}

\begin{tabular}{|c|c|c|c|c|c|c|c|}
\hline \multirow{2}{*}{$\begin{array}{l}\text { Amostra/ } \\
\text { Elemento }\end{array}$} & \multicolumn{7}{|c|}{ Suíte Granítica / Legenda: $○$} \\
\hline & Pto 23.B & Pto 51.A & Pto 51.B & Pto 52 & Pto 56.B & Pto 58 & VU-12 \\
\hline $\mathrm{SiO}_{2}$ & 69,05 & 72,17 & 68,91 & 66,42 & 67,69 & 71,76 & 63,29 \\
\hline $\mathrm{Al}_{2} \mathrm{O}_{3}$ & 15,42 & 13,46 & 14,88 & 14,79 & 15,15 & 14,77 & 14,4 \\
\hline $\mathrm{Fe}_{2} \mathrm{O}_{3}$ & 2,72 & 2,78 & 3,35 & 4,23 & 3,83 & 2,06 & 5,54 \\
\hline $\mathrm{MgO}$ & 0,79 & 0,44 & 0,62 & 1,22 & 1,01 & 0,31 & 2,9 \\
\hline $\mathrm{CaO}$ & 1,76 & 0,36 & 0,33 & 0,71 & 3,31 & 1,61 & 3,88 \\
\hline $\mathrm{Na}_{2} \mathrm{O}$ & 5,02 & 4,01 & 3,97 & 3,83 & 3,68 & 4,37 & 3,25 \\
\hline $\mathrm{K}_{2} \mathrm{O}$ & 3,31 & 5,42 & 5,88 & 5,69 & 3,01 & 3,67 & 4,06 \\
\hline $\mathrm{TiO}_{2}$ & 0,25 & 0,34 & 0,49 & 0,64 & 0,39 & 0,15 & 0,67 \\
\hline $\mathrm{P}_{2} \mathrm{O}_{5}$ & 0,1 & 0,1 & 0,13 & 0,23 & 0,13 & 0,05 & 0,22 \\
\hline $\mathrm{MnO}$ & 0,05 & 0,05 & 0,05 & 0,09 & 0,05 & 0,04 & 0,09 \\
\hline $\mathrm{Cr}_{2} \mathrm{O}_{3}$ & $<0,002$ & $<0,002$ & $<0,002$ & 0,002 & 0,005 & $<0,002$ & 0,012 \\
\hline LOI & 1,3 & 0,7 & 1,2 & 1,8 & 1,5 & 1,0 & 1,4 \\
\hline Mo & 0,4 & 0,4 & 0,5 & 1,7 & 10,1 & 1,2 & 1,3 \\
\hline $\mathrm{Cu}$ & 4,3 & 5,6 & 7 & 9,8 & 31,1 & 9,5 & 51,6 \\
\hline $\mathrm{Pb}$ & 58,7 & 99,2 & 11,7 & 16,9 & 15,2 & 10,4 & 33,1 \\
\hline $\mathrm{Zn}$ & 89 & 96 & 53 & 63 & 59 & 22 & 56 \\
\hline $\mathrm{Ni}$ & 4,5 & 1,8 & 2,3 & 5,1 & 4,2 & 2 & 23,6 \\
\hline As & 0,6 & $<0,5$ & 0,7 & 1 & 0,7 & $<0,5$ & 0,6 \\
\hline $\mathrm{Cd}$ & 0,2 & 0,2 & $<0,1$ & $<0,1$ & $<0,1$ & $<0,1$ & 0,2 \\
\hline $\mathrm{Sb}$ & $<0,1$ & $<0,1$ & $<0,1$ & 0,1 & $<0,1$ & $<0,1$ & $<0,1$ \\
\hline $\mathrm{Bi}$ & $<0,1$ & 0,2 & 0,6 & 0,2 & 0,3 & $<0,1$ & 0,6 \\
\hline $\mathrm{Ag}$ & $<0,1$ & $<0,1$ & $<0,1$ & $<0,1$ & 0,2 & $<0,1$ & 0,2 \\
\hline $\mathrm{Au}$ & $<0,5$ & 8,2 & 7,8 & 6,4 & 2,9 & 3 & $<0,5$ \\
\hline $\mathrm{Hg}$ & $<0,01$ & $<0,01$ & $<0,01$ & $<0,01$ & $<0,01$ & $<0,01$ & $<0,01$ \\
\hline $\mathrm{Tl}$ & $<0,1$ & $<0,1$ & $<0,1$ & $<0,1$ & $<0,1$ & $<0,1$ & $<0,1$ \\
\hline $\mathrm{Se}$ & $<0,5$ & $<0,5$ & 0,6 & $<0,5$ & $<0,5$ & $<0,5$ & $<0,5$ \\
\hline $\mathrm{Sc}$ & 3 & 3 & 6 & 8 & 4 & 1 & 11 \\
\hline $\mathrm{Ba}$ & 764 & 502 & 668 & 1437 & 1027 & 1308 & 1025 \\
\hline $\mathrm{Be}$ & 1 & 2 & 3 & 3 & 2 & 1 & 3 \\
\hline $\mathrm{Co}$ & 4,4 & 2,7 & 4,1 & 6,5 & 6,5 & 2,3 & 17,3 \\
\hline $\mathrm{Cs}$ & 0,5 & 0,3 & 0,4 & 0,8 & 0,7 & 0,4 & 1,3 \\
\hline $\mathrm{Ga}$ & 18,3 & 16,5 & 17,6 & 18,8 & 18,7 & 16,6 & 18,8 \\
\hline Hf & 3,4 & 7,6 & 9,4 & 10,4 & 3,2 & 2,7 & 7 \\
\hline
\end{tabular}

continua... 
Tabela 1 - Continuação.

\begin{tabular}{|c|c|c|c|c|c|c|c|}
\hline \multirow{2}{*}{$\begin{array}{l}\text { Amostra/ } \\
\text { Elemento }\end{array}$} & \multicolumn{7}{|c|}{ Suíte Granítica / Legenda: ○ } \\
\hline & Pto 23.B & Pto 51.A & Pto 51.B & Pto 52 & Pto 56.B & Pto 58 & VU-12 \\
\hline $\mathrm{Nb}$ & 5,5 & 15,4 & 16,7 & 16,5 & 7,4 & 6,5 & 14,2 \\
\hline $\mathrm{Rb}$ & 81,1 & 139,7 & 163 & 140,1 & 70,7 & 84,2 & 147,7 \\
\hline $\mathrm{Sn}$ & $<1$ & 2 & 2 & 2 & 1 & $<1$ & 2 \\
\hline $\mathrm{Sr}$ & 583,5 & 65,9 & 82 & 231,4 & 507 & 578,9 & 466,5 \\
\hline $\mathrm{Ta}$ & 0,3 & 1 & 0,9 & 0,9 & 0,4 & 0,2 & 0,9 \\
\hline Th & 12,7 & 17 & 18,5 & 17,8 & 7,2 & 5,7 & 17,8 \\
\hline $\mathrm{U}$ & 3,5 & 3,4 & 3,7 & 3,8 & 1,6 & 1,3 & 6,1 \\
\hline $\mathrm{V}$ & 26 & 16 & 22 & 38 & 46 & 19 & 102 \\
\hline W & $<0,5$ & 1 & 1 & 1,1 & $<0,5$ & $<0,5$ & 3 \\
\hline $\mathrm{Zr}$ & 117,5 & 281,3 & 350 & 410,2 & 119,6 & 91 & 248,7 \\
\hline $\mathrm{Y}$ & 7 & 63,4 & 41,1 & 43,4 & 11,1 & 5,5 & 22,9 \\
\hline$\overline{\mathrm{La}}$ & 25,2 & 54 & 76,7 & 83,2 & 32,3 & 19,1 & 50,5 \\
\hline $\mathrm{Ce}$ & 43,5 & 107 & 145,2 & 169,3 & 58 & 35 & 101,9 \\
\hline $\operatorname{Pr}$ & 4,47 & 11,88 & 18,79 & 19,01 & 6,75 & 3,9 & 12,22 \\
\hline $\mathrm{Nd}$ & 16,2 & 43,4 & 70,8 & 69,6 & 24,9 & 13,9 & 46,2 \\
\hline $\mathrm{Sm}$ & 1,94 & 6,11 & 10,4 & 10,36 & 3,67 & 2,04 & 7,25 \\
\hline $\mathrm{Eu}$ & 0,47 & 0,92 & 1,82 & 1,88 & 0,91 & 0,51 & 1,4 \\
\hline Gd & 1,56 & 5,97 & 8,67 & 8,66 & 2,9 & 1,4 & 5,54 \\
\hline $\mathrm{Tb}$ & 0,2 & 0,95 & 1,28 & 1,29 & 0,39 & 0,19 & 0,77 \\
\hline Dy & 0,97 & 6,04 & 7,03 & 7,04 & 1,81 & 1,01 & 3,98 \\
\hline Ho & 0,18 & 1,4 & 1,37 & 1,36 & 0,32 & 0,18 & 0,77 \\
\hline $\mathrm{Er}$ & 0,56 & 4,37 & 3,7 & 3,96 & 0,87 & 0,49 & 2,1 \\
\hline $\mathrm{Tm}$ & 0,08 & 0,75 & 0,59 & 0,62 & 0,14 & 0,08 & 0,34 \\
\hline $\mathrm{Yb}$ & 0,61 & 4,66 & 3,85 & 4,08 & 0,79 & 0,54 & 2,15 \\
\hline $\mathrm{Lu}$ & 0,1 & 0,76 & 0,58 & 0,61 & 0,13 & 0,09 & 0,33 \\
\hline$\Sigma$ ETR & 96,04 & 248,21 & 350,78 & 380,97 & 133,88 & 78,43 & 235,45 \\
\hline $\mathrm{Eu} / \mathrm{Eu}^{*}$ & 0,269 & 0,152 & 0,191 & 0,198 & 0,277 & 0,297 & 0,219 \\
\hline $\mathrm{FeOt} /(\mathrm{FeOt}+\mathrm{MgO})$ & 0,7749 & 0,8634 & 0,8438 & 0,7761 & 0,7913 & 0,8692 & 0,6564 \\
\hline $\mathrm{Na}_{2} \mathrm{O}+\mathrm{K}_{2} \mathrm{O}$ & 8,3300 & 9,4300 & 9,8500 & 9,5200 & 6,6900 & 8,0400 & 7,3100 \\
\hline $\mathrm{Al}_{2} \mathrm{O}_{3} /\left(\mathrm{Na}_{2} \mathrm{O}+\mathrm{K}_{2} \mathrm{O}\right)$ & 1,8511 & 1,4274 & 1,5107 & 1,5536 & 2,2646 & 1,8371 & 1,9699 \\
\hline $\mathrm{Al}_{2} \mathrm{O}_{3} /\left(\mathrm{Na}_{2} \mathrm{O}+\mathrm{K}_{2} \mathrm{O}+\mathrm{CaO}\right)$ & 1,5282 & 1,3749 & 1,4617 & 1,4457 & 1,5150 & 1,5306 & 1,2869 \\
\hline $\mathrm{Na}_{2} \mathrm{O}+\mathrm{K}_{2} \mathrm{O}-\mathrm{CaO}$ & 6,5700 & 9,0700 & 9,5200 & 8,8100 & 3,3800 & 6,4300 & 3,4300 \\
\hline \multirow{2}{*}{$\begin{array}{l}\text { Amostra/ } \\
\text { Elemento }\end{array}$} & \multicolumn{7}{|c|}{ Pórfiro União do Norte / Legenda: • } \\
\hline & FR-01 & FR-15 & FR-23 & & FR-24 & FR-27 & FR-78 \\
\hline $\mathrm{SiO}_{2}$ & 76,22 & 76,09 & 76,19 & & 75,64 & 76,29 & 75,25 \\
\hline $\mathrm{Al}_{2} \mathrm{O}_{3}$ & 11,77 & 11,93 & 11,79 & & 11,83 & 11,75 & 11,71 \\
\hline $\mathrm{Fe}_{2} \mathrm{O}_{3}$ & 1,72 & 1,59 & 1,69 & & 1,74 & 1,68 & 1,68 \\
\hline $\mathrm{MgO}$ & 0,23 & 0,09 & 0,13 & & 0,13 & 0,23 & 0,12 \\
\hline $\mathrm{CaO}$ & 0,3 & 0,34 & 0,39 & & 0,45 & 0,29 & 0,37 \\
\hline $\mathrm{Na}_{2} \mathrm{O}$ & 3,18 & 3,4 & 3,36 & & 3,51 & 3,17 & 3,36 \\
\hline $\mathrm{K}_{2} \mathrm{O}$ & 5,28 & 5,13 & 5,18 & & 5,24 & 5,24 & 5,2 \\
\hline $\mathrm{TiO}_{2}$ & 0,21 & 0,22 & 0,21 & & 0,2 & 0,21 & 0,19 \\
\hline $\mathrm{P}_{2} \mathrm{O}_{5}$ & 0,04 & 0,04 & 0,02 & & 0,03 & 0,03 & 0,03 \\
\hline
\end{tabular}


Contexto geológico e litogeoquímica das unidades plutônicas-vulcânicas da região de União do Norte, setor leste da Província Aurífera de Alta Floresta (MT)

Tabela 1 - Continuação.

\begin{tabular}{|c|c|c|c|c|c|c|}
\hline \multirow{2}{*}{$\begin{array}{l}\text { Amostra/ } \\
\text { Elemento }\end{array}$} & \multicolumn{6}{|c|}{ Pórfiro União do Norte / Legenda: • } \\
\hline & FR-01 & FR-15 & FR-23 & FR-24 & FR-27 & FR-78 \\
\hline $\mathrm{MnO}$ & 0,05 & 0,06 & 0,08 & 0,06 & 0,05 & 0,07 \\
\hline $\mathrm{Cr}_{2} \mathrm{O}_{3}$ & 0,006 & 0,007 & 0,006 & 0,006 & 0,006 & 0,008 \\
\hline LOI & 0,9 & 1 & 0,8 & 1,1 & 0,9 & 1,9 \\
\hline Mo & 2,3 & 1,4 & 1,4 & 3,4 & 2,2 & 1,1 \\
\hline $\mathrm{Cu}$ & 6,5 & 5,8 & 2,9 & 4,2 & 6,2 & 2,4 \\
\hline $\mathrm{Pb}$ & 18,6 & 152 & 30,7 & 17,5 & 17,7 & 35,4 \\
\hline $\mathrm{Zn}$ & 64 & 171 & 81 & 68 & 60 & 76 \\
\hline $\mathrm{Ni}$ & 1 & 1 & 0,8 & 0,8 & 0,8 & 1 \\
\hline As & 0,7 & 1 & $<0,5$ & $<0,5$ & $<0,5$ & 0,8 \\
\hline $\mathrm{Cd}$ & 0,2 & 0,4 & 0,2 & 0,1 & 0,2 & 0,1 \\
\hline $\mathrm{Sb}$ & $<0,1$ & $<0,1$ & $<0,1$ & $<0,1$ & $<0,1$ & 0,1 \\
\hline $\mathrm{Bi}$ & $<0,1$ & $<0,1$ & 0,8 & 0,4 & $<0,1$ & 0,2 \\
\hline $\mathrm{Ag}$ & $<0,1$ & 0,2 & 0,1 & 0,1 & $<0,1$ & 0,1 \\
\hline $\mathrm{Au}$ & $<0,5$ & $<0,5$ & $<0,5$ & $<0,5$ & $<0,5$ & $<0,5$ \\
\hline $\mathrm{Hg}$ & $<0,01$ & $<0,01$ & $<0,01$ & $<0,01$ & $<0,01$ & $<0,01$ \\
\hline $\mathrm{Tl}$ & $<0,1$ & $<0,1$ & $<0,1$ & $<0,1$ & $<0,1$ & $<0,1$ \\
\hline $\mathrm{Se}$ & 0,6 & 0,8 & $<0,5$ & 0,6 & 0,5 & 0,7 \\
\hline $\mathrm{Sc}$ & 3 & 3 & 3 & 3 & 3 & 3 \\
\hline $\mathrm{Ba}$ & 249 & 211 & 197 & 173 & 253 & 185 \\
\hline $\mathrm{Be}$ & 4 & 3 & 7 & 4 & 5 & 6 \\
\hline $\mathrm{Co}$ & 0,9 & 0,4 & 0,6 & 0,7 & 0,8 & 0,4 \\
\hline Cs & 0,8 & 0,7 & 0,8 & 0,9 & 0,7 & 1,1 \\
\hline $\mathrm{Ga}$ & 19,8 & 18,7 & 19,4 & 20,3 & 19,2 & 19,5 \\
\hline $\mathrm{Hf}$ & 10,9 & 12,2 & 11,1 & 12,8 & 11,6 & 11,3 \\
\hline $\mathrm{Nb}$ & 25,2 & 25,6 & 23,6 & 28,2 & 23,8 & 25,8 \\
\hline $\mathrm{Rb}$ & 213,3 & 210,4 & 224,5 & 251,4 & 211,5 & 257,8 \\
\hline $\mathrm{Sn}$ & 4 & 4 & 4 & 4 & 4 & 4 \\
\hline $\mathrm{Sr}$ & 25,6 & 30,8 & 24,3 & 29 & 23,8 & 26,2 \\
\hline $\mathrm{Ta}$ & 1,6 & 1,6 & 1,6 & 2 & 1,7 & 1,8 \\
\hline $\mathrm{Th}$ & 26,8 & 27,2 & 24,9 & 27,9 & 26,6 & 26,5 \\
\hline $\mathrm{U}$ & 7 & 7,1 & 6,5 & 8,3 & 7,4 & 7,9 \\
\hline $\mathrm{V}$ & $<8$ & $<8$ & $<8$ & $<8$ & $<8$ & $<8$ \\
\hline $\mathrm{W}$ & 0,9 & 0,6 & 0,7 & 0,8 & 0,8 & 0,9 \\
\hline $\mathrm{Zr}$ & 358,4 & 366 & 337,5 & 364,4 & 345,3 & 333,6 \\
\hline $\mathrm{Y}$ & 82,4 & 83,2 & 55 & 73,9 & 79,9 & 113,4 \\
\hline $\mathrm{La}$ & 118,3 & 119,5 & 77,7 & 80,9 & 119,7 & 109,6 \\
\hline $\mathrm{Ce}$ & 200,4 & 221,1 & 152,5 & 164,5 & 208,4 & 159,1 \\
\hline $\operatorname{Pr}$ & 26,23 & 25 & 17,8 & 18,43 & 26,31 & 21,89 \\
\hline $\mathrm{Nd}$ & 99,5 & 90,3 & 62,8 & 67 & 101,6 & 82,8 \\
\hline $\mathrm{Sm}$ & 17,24 & 14,76 & 10,74 & 12,18 & 17,09 & 13,48 \\
\hline $\mathrm{Eu}$ & 0,91 & 0,75 & 0,58 & 0,5 & 0,9 & 0,62 \\
\hline $\mathrm{Gd}$ & 15,89 & 12,84 & 8,88 & 10,16 & 16,02 & 13,05 \\
\hline $\mathrm{Tb}$ & 2,49 & 2,13 & 1,54 & 1,91 & 2,5 & 2,21 \\
\hline Dy & 13,44 & 11,88 & 8,96 & 11,28 & 13,37 & 12,63 \\
\hline
\end{tabular}

continua... 
Tabela 1 - Continuação.

\begin{tabular}{|c|c|c|c|c|c|c|c|c|c|}
\hline \multirow{2}{*}{$\begin{array}{l}\text { Amostra/ } \\
\text { Elemento }\end{array}$} & \multicolumn{9}{|c|}{ Pórfiro União do Norte / Legenda: • } \\
\hline & \multicolumn{2}{|l|}{ FR-01 } & FR-15 & \multicolumn{2}{|c|}{ FR-23 } & \multirow{2}{*}{$\begin{array}{c}\text { FR-24 } \\
2,43 \\
\end{array}$} & FR-27 & \multicolumn{2}{|r|}{ FR-78 } \\
\hline Ho & \multicolumn{2}{|l|}{2,77} & 2,53 & \multicolumn{2}{|l|}{1,9} & & \multicolumn{2}{|l|}{2,77} & 3,02 \\
\hline $\mathrm{Er}$ & \multicolumn{2}{|l|}{7,86} & 7,55 & \multicolumn{2}{|l|}{5,68} & 7,29 & \multicolumn{2}{|l|}{8,02} & 9,21 \\
\hline $\mathrm{Tm}$ & \multicolumn{2}{|l|}{1,17} & 1,17 & \multicolumn{2}{|l|}{0,95} & 1,17 & \multicolumn{2}{|l|}{1,2} & 1,4 \\
\hline $\mathrm{Yb}$ & 7,31 & & 7,78 & 6,23 & & 7,75 & 7,5 & & 8,8 \\
\hline $\mathrm{Lu}$ & 1,14 & & 1,14 & 0,92 & & 1,16 & 1,14 & & 1,34 \\
\hline$\Sigma$ ETR & 514,65 & & 518,43 & 357,18 & & 386,66 & 526,52 & & 439,15 \\
\hline $\mathrm{Eu} / \mathrm{Eu}^{*}$ & 0,055 & & 0,054 & 0,059 & & 0,045 & 0,054 & & 0,047 \\
\hline $\mathrm{FeOt} /(\mathrm{FeOt}+\mathrm{MgO})$ & 0,8821 & & 0,9464 & 0,9286 & & 0,9305 & 0,8796 & & 0,9333 \\
\hline $\mathrm{Na}_{2} \mathrm{O}+\mathrm{K}_{2} \mathrm{O}$ & 8,4600 & & 8,5300 & 8,5400 & & 8,7500 & 8,4100 & & 8,5600 \\
\hline $\mathrm{Al}_{2} \mathrm{O}_{3} /\left(\mathrm{Na}_{2} \mathrm{O}+\mathrm{K}_{2} \mathrm{O}\right)$ & 1,3913 & & 1,3986 & 1,3806 & & 1,3520 & 1,3971 & & 1,3680 \\
\hline $\mathrm{Al}_{2} \mathrm{O}_{3} /\left(\mathrm{Na}_{2} \mathrm{O}+\mathrm{K}_{2} \mathrm{O}+\mathrm{CaO}\right)$ & 1,3436 & & 1,3450 & 1,3203 & & 1,2859 & 1,3506 & & 1,3113 \\
\hline $\mathrm{Na}_{2} \mathrm{O}+\mathrm{K}_{2} \mathrm{O}-\mathrm{CaO}$ & 8,1600 & & 8,1900 & 8,1500 & & 8,3000 & 8,1200 & & 8,1900 \\
\hline Amostra/ & & & Diques d & Vulcânicas & Máficas a & Félsicas / I & genda: $\Delta$ & & \\
\hline Elemento & Pto 39.B & Pto 72 & Pto 42 & Pto 65.B & VU-19 & FR-31 & FR-40 & FR-46 & FR-56 \\
\hline $\mathrm{SiO}_{2}$ & 53,25 & 54,54 & 54,91 & 66,96 & 66,38 & 57,89 & 47,76 & 49,2 & 64,68 \\
\hline $\mathrm{Al}_{2} \mathrm{O}_{3}$ & 18,39 & 14,95 & 16,29 & 14,49 & 14,55 & 10,69 & 17,92 & 14,84 & 16,32 \\
\hline $\mathrm{Fe}_{2} \mathrm{O}_{3}$ & 8,75 & 7,98 & 8,01 & 5,35 & 5,69 & 7,5 & 11,54 & 9,89 & 4,59 \\
\hline $\mathrm{MgO}$ & 3,2 & 5,61 & 4,59 & 0,94 & 0,98 & 10,04 & 4,75 & 7,84 & 1,81 \\
\hline $\mathrm{CaO}$ & 6,49 & 6,85 & 6,97 & 3,02 & 3,17 & 5,66 & 7 & 8,51 & 3,52 \\
\hline $\mathrm{Na}_{2} \mathrm{O}$ & 4 & 3,65 & 3,52 & 2,75 & 2,81 & 2,38 & 3,45 & 2,9 & 3,58 \\
\hline $\mathrm{K}_{2} \mathrm{O}$ & 2,24 & 2,39 & 1,79 & 3,59 & 3,59 & 1,61 & 1,55 & 1,95 & 2,58 \\
\hline $\mathrm{TiO}_{2}$ & 0,81 & 0,65 & 0,95 & 0,54 & 0,58 & 0,53 & 1,09 & 0,6 & 0,62 \\
\hline $\mathrm{P}_{2} \mathrm{O}_{5}$ & 0,3 & 0,29 & 0,24 & 0,17 & 0,17 & 0,11 & 0,26 & 0,23 & 0,13 \\
\hline $\mathrm{MnO}$ & 0,12 & 0,15 & 0,16 & 0,09 & 0,09 & 0,21 & 0,15 & 0,16 & 0,09 \\
\hline $\mathrm{Cr}_{2} \mathrm{O}_{3}$ & 0,002 & 0,027 & 0,013 & 0,002 & 0,003 & 0,138 & $<0,002$ & 0,059 & 0,006 \\
\hline LOI & 2,1 & 2,5 & 2,2 & 1,8 & 1,7 & 2,9 & 4,2 & 3,5 & 1,9 \\
\hline Mo & 0,8 & 0,7 & 0,5 & 0,6 & 0,4 & 0,5 & 0,3 & 0,4 & 0,1 \\
\hline $\mathrm{Cu}$ & 109,3 & 68,7 & 33,9 & 16,4 & 15,4 & 50,8 & 55,2 & 117,7 & 3 \\
\hline $\mathrm{Pb}$ & 26,2 & 8,1 & 31,1 & 10,3 & 11 & 2,4 & 18,3 & 52,1 & 7,3 \\
\hline $\mathrm{Zn}$ & 100 & 82 & 122 & 47 & 54 & 113 & 93 & 39 & 73 \\
\hline $\mathrm{Ni}$ & 15,1 & 29,6 & 30,4 & 5,9 & 7,3 & 227,3 & 9,7 & 68,1 & 15,4 \\
\hline As & 1,2 & 1,4 & 1,6 & 1,9 & 2,5 & 0,8 & 1 & 1,4 & 1,1 \\
\hline $\mathrm{Cd}$ & 0,1 & $<0,1$ & 0,3 & $<0,1$ & $<0,1$ & $<0,1$ & $<0,1$ & $<0,1$ & $<0,1$ \\
\hline $\mathrm{Sb}$ & 0,2 & $<0,1$ & 0,5 & 0,1 & 0,1 & 0,3 & 0,1 & 0,2 & 0,2 \\
\hline $\mathrm{Bi}$ & $<0,1$ & $<0,1$ & 0,1 & 0,1 & 0,1 & $<0,1$ & $<0,1$ & $<0,1$ & 0,1 \\
\hline $\mathrm{Ag}$ & 0,2 & $<0,1$ & 0,2 & $<0,1$ & 0,1 & 0,1 & $<0,1$ & 0,3 & $<0,1$ \\
\hline $\mathrm{Au}$ & 1,7 & 2 & 16,5 & 3,1 & 0,6 & $<0,5$ & $<0,5$ & 1,8 & 0,6 \\
\hline $\mathrm{Hg}$ & $<0,01$ & $<0,01$ & $<0,01$ & $<0,01$ & $<0,01$ & $<0,01$ & $<0,01$ & $<0,01$ & $<0,01$ \\
\hline $\mathrm{Tl}$ & 0,1 & $<0,1$ & 0,2 & $<0,1$ & $<0,1$ & 0,2 & 0,1 & 0,2 & 0,2 \\
\hline $\mathrm{Se}$ & $<0,5$ & $<0,5$ & $<0,5$ & $<0,5$ & 0,6 & $<0,5$ & $<0,5$ & $<0,5$ & $<0,5$ \\
\hline $\mathrm{Sc}$ & 19 & 19 & 19 & 7 & 7 & 20 & 17 & 28 & 12 \\
\hline $\mathrm{Ba}$ & 736 & 1302 & 771 & 1183 & 1134 & 322 & 468 & 542 & 739 \\
\hline $\mathrm{Be}$ & $<1$ & 1 & $<1$ & 3 & 2 & 3 & $<1$ & 1 & 2 \\
\hline
\end{tabular}


Contexto geológico e litogeoquímica das unidades plutônicas-vulcânicas da região de União do Norte, setor leste da Província Aurífera de Alta Floresta (MT)

Tabela 1 - Continuação.

\begin{tabular}{|c|c|c|c|c|c|c|c|c|c|}
\hline \multirow{2}{*}{$\begin{array}{l}\text { Amostra/ } \\
\text { Elemento }\end{array}$} & \multicolumn{9}{|c|}{ Diques de Vulcânicas Máficas a Félsicas / Legenda: $\Delta$} \\
\hline & Pto 39.B & Pto 72 & Pto 42 & Pto 65.B & VU-19 & FR-31 & FR-40 & FR-46 & FR-56 \\
\hline Co & 26 & 29 & 26,2 & 10 & 10,1 & 39,7 & 35,6 & 36,1 & 11,1 \\
\hline Cs & 3,2 & 1 & 1,8 & 3 & 2,5 & 2,9 & 1,8 & 3,8 & 2,3 \\
\hline $\mathrm{Ga}$ & 20,6 & 18,4 & 20,2 & 18,8 & 18,2 & 14,7 & 18,1 & 15,1 & 17,8 \\
\hline $\mathrm{Hf}$ & 3,3 & 3,4 & 4 & 5,9 & 5,9 & 3,3 & 2 & 1,7 & 4,1 \\
\hline $\mathrm{Nb}$ & 5,3 & 5,7 & 7,7 & 11,2 & 11,7 & 9,2 & 2,8 & 2 & 8,2 \\
\hline $\mathrm{Rb}$ & 82,9 & 58,9 & 63,8 & 116,9 & 118,9 & 73,8 & 69,3 & 117,8 & 103 \\
\hline $\mathrm{Sn}$ & $<1$ & 1 & 1 & 3 & 2 & 2 & $<1$ & $<1$ & 2 \\
\hline $\mathrm{Sr}$ & 1047,7 & 1058,4 & 598,4 & 902,1 & 936,9 & 421,2 & 1158,6 & 1169,1 & 480,5 \\
\hline $\mathrm{Ta}$ & 0,1 & $<0,1$ & 0,2 & 0,6 & 0,6 & 0,7 & 0,1 & $<0,1$ & 0,6 \\
\hline Th & 2,3 & 4,3 & 4,5 & 13,2 & 12,8 & 14,2 & 1,1 & 1,2 & 9,9 \\
\hline $\mathrm{U}$ & 0,8 & 1,5 & 1,1 & 3,1 & 3,2 & 4,1 & 0,3 & 0,6 & 2,7 \\
\hline $\mathrm{V}$ & 200 & 162 & 170 & 81 & 85 & 132 & 279 & 296 & 79 \\
\hline W & $<0,5$ & 0,9 & 0,9 & 1,3 & 1,1 & 1,2 & $<0,5$ & $<0,5$ & 2,4 \\
\hline $\mathrm{Zr}$ & 127,1 & 126,2 & 151,3 & 207,8 & 213,4 & 89,5 & 68,1 & 52,9 & 133,7 \\
\hline $\mathrm{Y}$ & 15,4 & 16,7 & 20,7 & 31,1 & 26,7 & 17,8 & 12,4 & 11,1 & 17,9 \\
\hline $\mathrm{La}$ & 22,8 & 27,5 & 25,6 & 42,7 & 41,4 & 24,2 & 14,4 & 11,4 & 33,2 \\
\hline $\mathrm{Ce}$ & 45,7 & 56,8 & 53,7 & 86,3 & 83 & 45,7 & 30,5 & 23 & 66,8 \\
\hline $\operatorname{Pr}$ & 5,37 & 6,93 & 6,59 & 10,41 & 10,07 & 4,96 & 4,02 & 2,94 & 7,73 \\
\hline $\mathrm{Nd}$ & 22,5 & 28,6 & 28,1 & 38,7 & 37,6 & 18,8 & 16,8 & 13,1 & 30,2 \\
\hline $\mathrm{Sm}$ & 3,66 & 4,7 & 4,83 & 6,69 & 6,39 & 3,15 & 3,5 & 2,59 & 5,15 \\
\hline $\mathrm{Eu}$ & 1,05 & 1,29 & 1,3 & 1,33 & 1,28 & 0,68 & 1,21 & 0,85 & 1,37 \\
\hline $\mathrm{Gd}$ & 3,67 & 3,83 & 4,69 & 5,54 & 5,22 & 2,84 & 3,1 & 2,35 & 3,9 \\
\hline $\mathrm{Tb}$ & 0,48 & 0,57 & 0,67 & 0,87 & 0,81 & 0,48 & 0,46 & 0,36 & 0,61 \\
\hline Dy & 2,62 & 3,23 & 3,59 & 4,81 & 4,44 & 2,61 & 2,28 & 2,07 & 3,09 \\
\hline Ho & 0,49 & 0,6 & 0,69 & 1 & 0,91 & 0,58 & 0,47 & 0,42 & 0,63 \\
\hline $\mathrm{Er}$ & 1,35 & 1,8 & 1,85 & 3,19 & 2,8 & 1,8 & 1,24 & 1,17 & 1,84 \\
\hline $\mathrm{Tm}$ & 0,2 & 0,26 & 0,29 & 0,49 & 0,43 & 0,32 & 0,19 & 0,19 & 0,28 \\
\hline $\mathrm{Yb}$ & 1,28 & 1,52 & 1,85 & 3,01 & 2,72 & 2,05 & 1,16 & 1,23 & 1,8 \\
\hline $\mathrm{Lu}$ & 0,2 & 0,25 & 0,27 & 0,47 & 0,43 & 0,33 & 0,17 & 0,18 & 0,27 \\
\hline इETR & 111,37 & 137,88 & 134,02 & 205,51 & 197,5 & 108,5 & 79,5 & 61,85 & 156,87 \\
\hline $\mathrm{Eu} / \mathrm{Eu}^{*}$ & 0,286 & 0,302 & 0,273 & 0,217 & 0,220 & 0,227 & 0,367 & 0,344 & 0,303 \\
\hline $\mathrm{FeOt} /(\mathrm{FeOt}+\mathrm{MgO})$ & 0,7322 & 0,5872 & 0,6357 & 0,8506 & 0,8531 & 0,4276 & 0,7084 & 0,5578 & 0,7172 \\
\hline $\mathrm{Na}_{2} \mathrm{O}+\mathrm{K}_{2} \mathrm{O}$ & 6,2400 & 6,0400 & 5,3100 & 6,3400 & 6,4000 & 3,9900 & 5,0000 & 4,8500 & 6,1600 \\
\hline $\mathrm{Al}_{2} \mathrm{O}_{3} /\left(\mathrm{Na}_{2} \mathrm{O}+\mathrm{K}_{2} \mathrm{O}\right)$ & 2,9471 & 2,4752 & 3,0678 & 2,2855 & 2,2734 & 2,6792 & 3,5840 & 3,0598 & 2,6494 \\
\hline $\mathrm{Al}_{2} \mathrm{O}_{3} /\left(\mathrm{Na}_{2} \mathrm{O}+\mathrm{K}_{2} \mathrm{O}+\mathrm{CaO}\right)$ & 1,4446 & 1,1598 & 1,3265 & 1,5481 & 1,5204 & 1,1078 & 1,4933 & 1,1108 & 1,6860 \\
\hline $\mathrm{Na}_{2} \mathrm{O}+\mathrm{K}_{2} \mathrm{O}-\mathrm{CaO}$ & $-0,2500$ & $-0,8100$ & $-1,6600$ & 3,3200 & 3,2300 & $-1,6700$ & $-2,0000$ & $-3,6600$ & 2,6400 \\
\hline
\end{tabular}

\begin{tabular}{|c|c|c|c|c|}
\hline \multirow{2}{*}{$\begin{array}{l}\text { Amostra/ } \\
\text { Elemento }\end{array}$} & \multicolumn{4}{|c|}{ Unidade Vulcanoclástica / Legenda: • } \\
\hline & FR-01T & FR-04 & FR-34 & PTO 19S \\
\hline $\mathrm{SiO}_{2}$ & 72,12 & 81,58 & 72,13 & 71,78 \\
\hline $\mathrm{Al}_{2} \mathrm{O}_{3}$ & 12,31 & 8,34 & 11,54 & 11,64 \\
\hline $\mathrm{Fe}_{2} \mathrm{O}_{3}$ & 3,13 & 2,05 & 2,48 & 3,96 \\
\hline $\mathrm{MgO}$ & 1,28 & 0,12 & 1,58 & 1,51 \\
\hline $\mathrm{CaO}$ & 1,34 & 0,31 & 2,22 & 2,04 \\
\hline
\end{tabular}

continua... 
Tabela 1 - Continuação.

\begin{tabular}{|c|c|c|c|c|}
\hline \multirow{2}{*}{$\begin{array}{l}\text { Amostra/ } \\
\text { Elemento }\end{array}$} & \multicolumn{4}{|c|}{ Unidade Vulcanoclástica / Legenda: • } \\
\hline & FR-01T & FR-04 & FR-34 & PTO 19S \\
\hline $\mathrm{Na}_{2} \mathrm{O}$ & 4,72 & 0,97 & 3,65 & 4,21 \\
\hline $\mathrm{K}_{2} \mathrm{O}$ & 3,69 & 5,11 & 4,3 & 3,59 \\
\hline $\mathrm{TiO}_{2}$ & 0,33 & 0,31 & 0,3 & 0,41 \\
\hline $\mathrm{P}_{2} \mathrm{O}_{5}$ & 0,07 & 0,06 & 0,1 & 0,09 \\
\hline $\mathrm{MnO}$ & 0,07 & 0,04 & 0,08 & 0,08 \\
\hline $\mathrm{Cr}_{2} \mathrm{O}_{3}$ & 0,017 & 0,015 & 0,012 & 0,024 \\
\hline LOI & 0,8 & 0,9 & 1,5 & 0,5 \\
\hline Mo & $<0,1$ & 0,3 & 0,1 & 0,1 \\
\hline $\mathrm{Cu}$ & 2 & 6,1 & 1,3 & 1,6 \\
\hline $\mathrm{Pb}$ & 6,3 & 6,2 & 6,7 & 5 \\
\hline $\mathrm{Zn}$ & 54 & 14 & 23 & 18 \\
\hline $\mathrm{Ni}$ & 3,8 & 3,8 & 3,7 & 2,9 \\
\hline As & 6,6 & $<0,5$ & 7,1 & 3,4 \\
\hline $\mathrm{Cd}$ & 0,1 & $<0,1$ & $<0,1$ & $<0,1$ \\
\hline $\mathrm{Sb}$ & 0,4 & 0,1 & 2 & 0,8 \\
\hline $\mathrm{Bi}$ & 0,1 & 0,1 & $<0,1$ & $<0,1$ \\
\hline $\mathrm{Ag}$ & 0,1 & $<0,1$ & $<0,1$ & $<0,1$ \\
\hline $\mathrm{Au}$ & $<0,5$ & 0,7 & $<0,5$ & 9,6 \\
\hline $\mathrm{Hg}$ & $<0,01$ & $<0,01$ & $<0,01$ & $<0,01$ \\
\hline $\mathrm{Tl}$ & $<0,1$ & $<0,1$ & $<0,1$ & 0,1 \\
\hline $\mathrm{Se}$ & $<0,5$ & $<0,5$ & $<0,5$ & $<0,5$ \\
\hline $\mathrm{Sc}$ & 6 & 3 & 6 & 8 \\
\hline $\mathrm{Ba}$ & 672 & 868 & 777 & 621 \\
\hline $\mathrm{Be}$ & 2 & 1 & 3 & 2 \\
\hline $\mathrm{Co}$ & 6,4 & 2,3 & 7,6 & 9,9 \\
\hline $\mathrm{Cs}$ & 0,8 & 1,4 & 1,2 & 0,9 \\
\hline $\mathrm{Ga}$ & 12 & 8,4 & 10,9 & 10,8 \\
\hline Hf & 4,1 & 7,5 & 3,8 & 5,9 \\
\hline $\mathrm{Nb}$ & 5,6 & 7,2 & 5,8 & 6,2 \\
\hline $\mathrm{Rb}$ & 81,5 & 121,6 & 104,4 & 84,4 \\
\hline $\mathrm{Sn}$ & 1 & 2 & 1 & $<1$ \\
\hline $\mathrm{Sr}$ & 147,2 & 97,6 & 171 & 155,2 \\
\hline $\mathrm{Ta}$ & 0,4 & 0,6 & 0,6 & 0,4 \\
\hline Th & 8,3 & 6,5 & 7,6 & 8,6 \\
\hline $\mathrm{U}$ & 1,1 & 1,1 & 1,4 & 1,3 \\
\hline $\mathrm{V}$ & 12 & 18 & 14 & 31 \\
\hline W & 3,2 & 2,1 & 2 & 4 \\
\hline $\mathrm{Zr}$ & 147,7 & 265,3 & 139 & 232,3 \\
\hline $\mathrm{Y}$ & 19,8 & 14,2 & 16 & 16,5 \\
\hline $\mathrm{La}$ & 21,5 & 21,8 & 19,3 & 21,9 \\
\hline $\mathrm{Ce}$ & 37,6 & 43,4 & 38,4 & 55,7 \\
\hline $\mathrm{Pr}$ & 5,38 & 5,31 & 4,5 & 4,89 \\
\hline $\mathrm{Nd}$ & 20,4 & 19,3 & 18 & 18,1 \\
\hline $\mathrm{Sm}$ & 3,92 & 3,29 & 3,11 & 3,47 \\
\hline
\end{tabular}

continua... 
Tabela 1 - Continuação.

\begin{tabular}{ccccc}
\hline \multirow{2}{*}{$\begin{array}{c}\text { Emostra/ } \\
\text { Elemento }\end{array}$} & \multicolumn{4}{c}{ Unidade Vulcanoclástica / Legenda: } \\
\cline { 2 - 5 } & FR-01T & FR-04 & FR-34 & PTO 19S \\
\hline $\mathrm{Eu}$ & 0,84 & 0,7 & 0,7 & 0,79 \\
\hline $\mathrm{Gd}$ & 3,22 & 2,52 & 2,6 & 0,48 \\
\hline $\mathrm{Tb}$ & 0,55 & 0,42 & 0,43 & 2,82 \\
\hline $\mathrm{Dy}$ & 3,09 & 2,21 & 0,6 \\
\hline $\mathrm{Ho}$ & 0,62 & 0,46 & 0,5 & 1,69 \\
\hline $\mathrm{Er}$ & 1,79 & 1,39 & 0,26 \\
\hline $\mathrm{Tm}$ & 0,28 & 0,22 & 0,24 & 1,77 \\
\hline $\mathrm{Yb}$ & 1,78 & 1,46 & 1,61 & 0,25 \\
\hline $\mathrm{Lu}$ & 0,27 & 0,24 & 0,25 & 115,58 \\
\hline $\mathrm{ETR}$ & 101,24 & 102,72 & 93,46 & 0,250 \\
\hline $\mathrm{Eu} / \mathrm{Eu} *$ & 0,235 & 0,241 & 0,245 & \\
\hline
\end{tabular}

\section{CONTEXTO GEOLÓGICO LOGAL}

Geologia e Petrografia As principais unidades litodêmicas da região de União do Norte, sudeste da PAAF, incluem: uma unidade vulcanoclástica, três suítes plutônicas, diques de vulcânicas máficas a félsicas, além de uma sequência sedimentar siliciclástica (Fig. 3).

\section{UNIDADE VULCANOCLÁSTICA Essencialmente} representada por grauvaca-feldspática vulcanoclástica, arcóseo lítico vulcanoclástico, arenito arcoseano vulcanoclástico, todos de granulação muito fina a fina, além de lentes subordinadas de conglomerado arenoso polimítico vulcanoclástico matriz suportado (Assis 2008, 2011). Corresponde à unidade que hospeda o depósito aurífero associado a metais de base do Francisco.

Arenito arcoseano Restrito às cotas mais elevadas, é representado por rochas de tonalidade bege a creme clara, brilho sedoso, granulometria muito fina a fina, estrutura laminada e acamadada. O S mostra orientação preferencial entre N22-63E/10-17SE, além de orientações N07-27W/07-50SW subordinadas.

Grauvaca-feldspática vulcanoclástica Caracteriza-se por apresentar coloração cinza-claro a amarronada, estrutura maciça ou com estratificação plano-paralela a cruzada centimétricas e gradação granulométrica descontínua (Fig. 4A). Por vezes, leitos de granulometria muito fina são realçados pela elevada quantidade de magnetitathematita. $\mathrm{O} \mathrm{S}_{0}$ desta litofácies, quando reconhecido, revela mergulhos entre $35^{\circ}$ e $45^{\circ}$ para ESE e WSW indicando ter sido sujeita a dobramento. Entretanto, devido ao grau de intemperismo e à falta de afloramentos contínuos, essas relações estruturais ainda necessitam de investigação mais sistemática.

Há predominância de grãos e cristais angulosos a subangulosos de baixa a moderada esfericidade (Fig. 4B), constituídos eminentemente por quartzo (20-33\%), feldspato potássico (21-27\%), plagioclásio (14-15\%), cimento silicoso (11\%) e fragmentos líticos (18-22\%), esses últimos essencialmente de origem vulcânica (Fig. 4C). Fragmentos graníticos, embora incomuns, também são observados. Os fragmentos líticos e de cristais encontram-se envolvidos por uma matriz silicosa que totaliza 16,7 a $18,3 \%$ da rocha. Os cristais de quartzo são angulosos a arredondados, com predomínio de formas subangulares. Microclínio e ortoclásio correspondem ao feldspato dominante. O microclínio, por vezes, exibe texturas de exsolução e pertíticas, indicando uma possível origem granítica.

Arenito arcoseano lítico vulcanoclástico Exibe tonalidades rósea-amarelada, amarronada a acinzentada, além de estratificação plano-paralela por vezes intercalada a estratificações cruzadas de pequeno porte (Fig. 4D). Leitos de 1,5-2 cm de espessura constituídos por hematita \pm magnetita podem ocorrer paralelamente ao acamamento. Os fragmentos líticos e de cristais exibem heterogeneidade quanto à forma e granulometria, com grãos subarredondados a angulares, de aspecto fragmentado, indicando curto transporte e baixo retrabalhamento. São litofácies constituídas por quartzo (33\%), plagioclásio (21\%), fragmentos líticos $(16 \%)$, feldspato alcalino (5\%), matriz silicosa (8\%) e cimento argiloso $(\sim 5 \%)$. Novamente, os fragmentos vulcânicos são abundantes, enquanto os graníticos ocorrem em menores quantidades. 


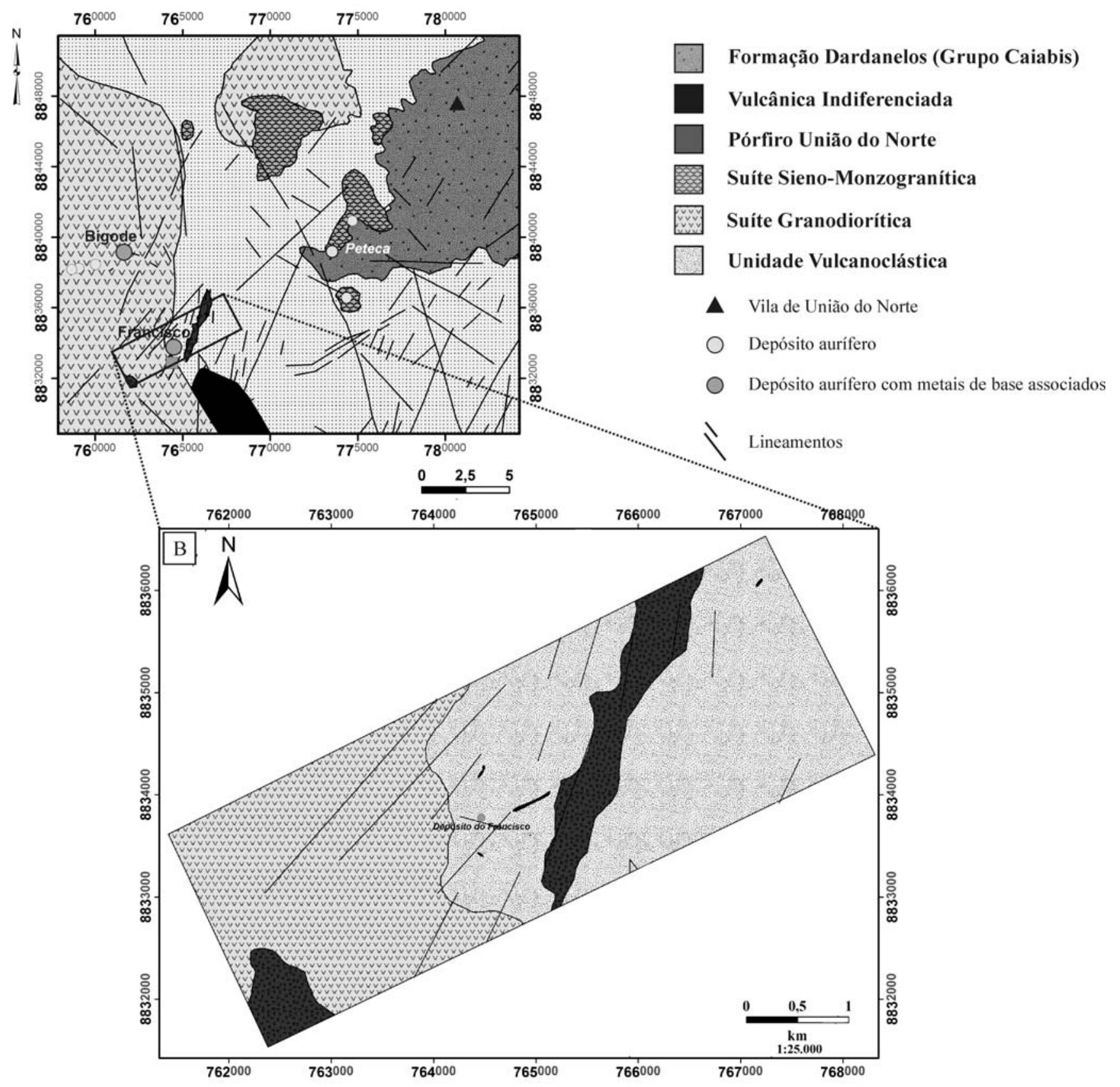

Figura 3 - (A) Mapa geológico da região de União do Norte com a localização dos depósitos auríferos do Francisco e do Bigode; (B) Mapa geológico de semidetalhe (1:25.000) do entorno do Depósito do Francisco (Assis 2011).

Conglomerado arenoso polimítico vulcanoclástico matriz suportada Essa litofácies raramente aflora, sendo identificada principalmente em furos de sondagem, onde ocorre em camadas de até $12 \mathrm{~m}$ de espessura, intercaladas entre camadas do arenito arcoseano lítico vulcanoclástico, com o qual o contato é brusco. Os fragmentos líticos, essencialmente de vulcânicas intermediárias, perfazem $39-77 \%$ do volume da rocha, sendo representados por clastos com dimensões de até $7 \mathrm{~cm}$ de comprimento imersos em matriz de areia fina a média (Fig. 4E).
SUÍTES PLUTÔNICAS Três suítes de rochas graníticas encontram-se representadas na região de União do Norte: 1) suíte granodiorítica; 2) suíte granítica; e 3) Pórfiro União do Norte (Fig. 5). Essas suítes exibem localmente contatos bruscos com a Unidade Vulcanoclástica, indicando serem intrusivas e, portanto, mais jovens.

Suíte Granodiorítica (SGN) Representada por granodiorito, tonalito subordinado e raro quartzo monzodiorito. Ocorre na forma de blocos e matações métricos a 

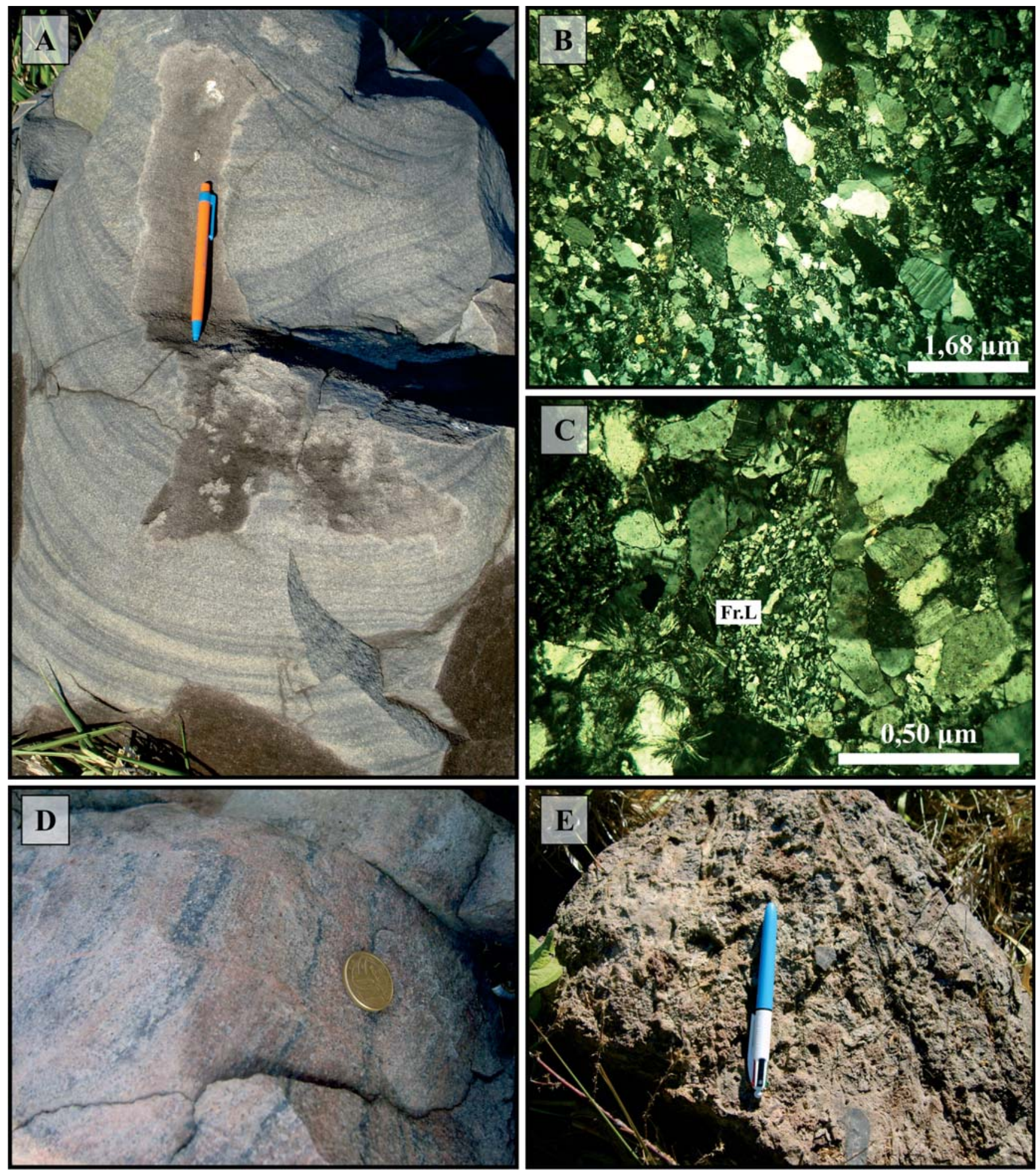

Figura 4 - (A) Grauvaca-feldspática de granulometria fina e laminação plano-paralela e cruzada. Fotomicrografias (polarizadores cruzados) exibindo (B) Laminação bem pronunciada e definida pela orientação dos cristais e fragmentos rochosos em grauvaca-feldspática vulcanoclástica; (C) Fragmento vulcânico com textura subofítica; (D) Arenito arcoseano lítico vulcanoclástico com estratificação plano-paralela bem definida e leitos de até 2,5 cm de espessura, constituídos por hematita+magnetita; (E) Conglomerado polimítico arenoso matriz suportado, com clastos angulosos a subangulosos de até $6 \mathrm{~cm}$ de comprimento. 


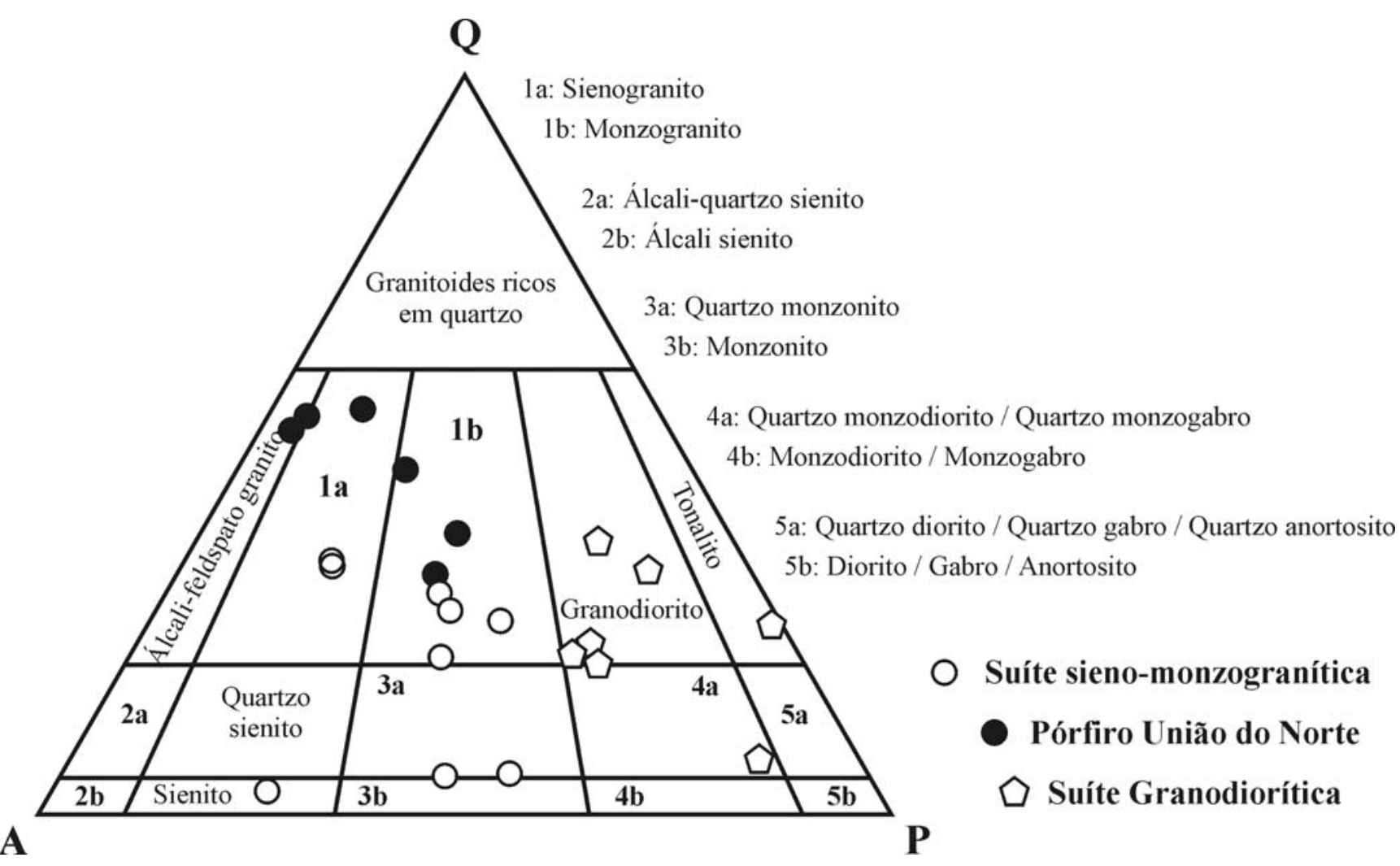

Figura 5 - Classificação petrográfica modal de amostras representativas das suítes plutônicas da região de União do Norte.

submétricos em região de relevo aplainado. O granodiorito é isotrópico, de coloração cinza-claro com porções levemente rosadas, de granulação média a grossa e textura inequigranular hipidiomórfica a automórfica, com cristais que exibem contatos predominantemente planares (Figs. 6A e B). Texturas intersticial e granofírica ocorrem subordinadamente. São constituídos por labradorita (41-47\%), quartzo (17-28\%), feldspato alcalino (10-18\%), hornblenda (3-16\%) e biotita ( $4 \%)$. Titanita, magnetita por vezes com lamelas de ilmenita, apatita e zircão ocorrem como fases acessórias, enquanto que clorita, epídoto, clinozoisita, hematita, sericita, pirita e calcopirita retratam fases hidrotermais. Biotita, hornblenda, titanita, apatita e magnetita normalmente ocorrem em paragênese (Fig. 6C). O quartzo é predominantemente intersticial, fragmentado e de moderada extinção ondulante. A labradorita, com frequente zoneamento oscilatório, forma cristais tabulares justapostos ou calçados. A biotita é tabular, parcialmente cloritizada e por vezes exibe lamelas de prehnita ao longo de suas clivagens, enquanto que a hornblenda pode apresentar núcleos desestabilizados com pequenas inclusões de quartzo.

Os termos tonalíticos, no entanto, são representados por rochas de tonalidade verde-acinzentado, granulação média e textura porfirítica denotada por cristais de labradorita e hornblenda. São isotrópicos, fracamente magnéticos, inequigranulares e predominantemente automórficos, com cristais que exibem contatos planares e textura em calçamento. São constituídos por plagioclásio $(61 \%)$, quartzo $(21 \%)$, hornblenda $(8 \%)$, biotita $(\sim 2 \%)$ e feldspato potássico $(1 \%)$. Titanita, magnetita e apatita ocorrem como acessórios, enquanto clorita, epídoto, hematita, pirita, muscovita, sericita e rutilo como fases secundárias.

Suíte Granítica (SGR) Composta por sieno-monzogranitos e ocorrências restritas de sienito e quartzo-monzonito (Fig. 5). São rochas geralmente de tonalidades róseas, não magnéticas, isotrópicas, granulação média a grossa, inequigranulares, com texturas poiquilítica, porfirítica e, por vezes, rapakivi (Figs. 6D a F). Enclaves de granodiorito, embora raros, indicam uma idade mais jovem ou contemporânea a SGR. Zonas de cisalhamento centimétricas e restritas afetam essa suíte, gerando intensa venulação preenchida por quartzo. São compostas essencialmente por feldspato alcalino (39$42 \%$ ), plagioclásio (23-36\%) e quartzo (10-28\%). Zircão, apatita, allanita, magnetita e biotita ocorrem como fases acessórias, enquanto que sericita, clorita, epídoto e pirita como fases secundárias. A textura gráfica é frequente nas rochas da suíte mais ricas em quartzo, 

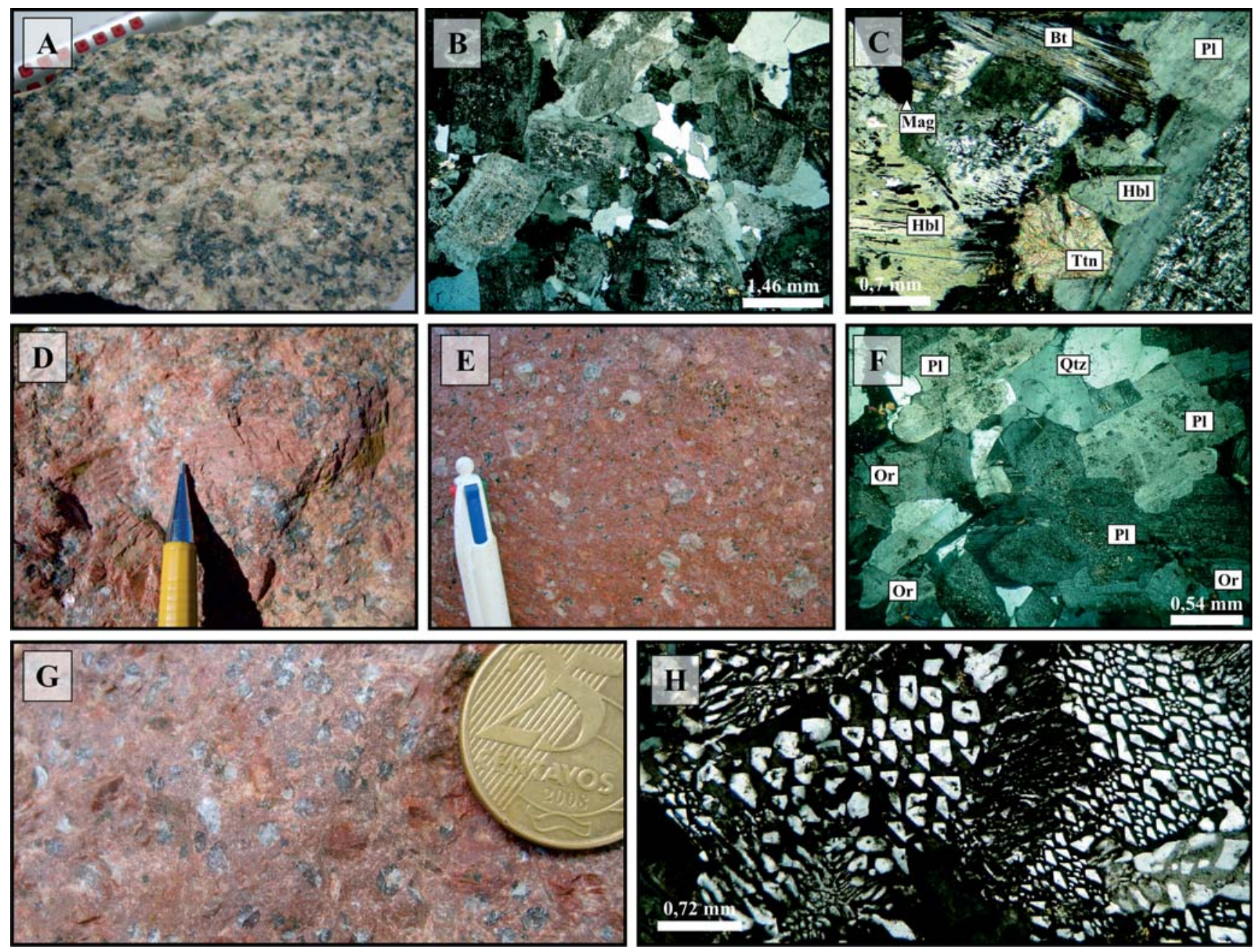

Figura 6 - Suíte Granodiorítica: (A) Granodiorito fanerítico grosso, isotrópico e inequigranular; Fotomicrografias: (B) Granodiorito médio de textura hipidiomórfica; (C) Biotita, hornblenda, titanita e magnetita que frequentemente ocorrem em paragênese. Suíte Granítica: (D) Quartzo intersticial e cristais de feldspato alcalino de granulação média a grossa; (E) Coloração avermelhada, textura inequigranular, por vezes porfirítica, de monzogranito; (F) Fotomicrografia exibindo texturas inequigranular e hipidiomórfica, típicas das rochas dessa suíte. Pórfiro União do Norte: $(G)$ Textura porfirítica representada por cristais de feldspato alcalino e quartzo arredondado a biterminado; e (H) Fotomicrografia de textura micrográfica. Legenda: quartzo (Qtz); plagioclásio (Pl); ortoclásio (Or); magnetita (Mag); hornblenda (Hbl); biotita (Bt); titanita (Ttn). Fotomicrografias com os polarizadores cruzados.

enquanto texturas mesopertítica, micropertítica e mimerquítica também podem estar presentes.

Pórfiro União do Norte (PFU) A denominação de PFU adotada neste trabalho é para designar uma suíte subvulcânica até então não individualizada nos mapas geológicos mais recentes da PAAF (Souza et al. 2005, Moreton \& Martins 2005) e da região de União do Norte (Assis 2008). Corresponde a uma unidade de quartzo-feldspato pórfiro composta por álcali-feldspato granito porfirítico a monzogranito porfirítico (Fig. 5) que ocorrem na forma de lacólitos dispostos ao longo de um alinhamento de serras de direção NE-SW. Exibem contatos intrusivos com as unidades anteriores, além de conter enclaves de rochas vulcanoclásticas, indicando, portanto, ser mais jovem que essa unidade. As regiões de contato são representadas por uma intensa geração de veios e sistema de veios quartzosos.

É representado por rochas de tonalidade vermelho-tijolo, não magnéticas, isotrópicas, holocristalinas, de textura porfirítica, micrográfica e granofírica características (Figs. 6G e H), sendo as duas últimas indicativas da saturação em fase fluida decorrente da cristalização magmática em nível crustal raso (Candela 1997, Wernick 2004). Os fenocristais, dispersos em matriz fanerítica fina de textura micrográfica bem desenvolvida, 
exibem granulação média a grossa, formatos subeuédricos a euédricos, contatos retilíneos com a matriz e não ultrapassam 25-30\% do volume da rocha (Fig. 6G). São representados por: (1) quartzo azulado, arredondado a biterminado, com diâmetro de até $7 \mathrm{~mm}$ e que frequentemente exibem golfos de corrosão atribuídos à dissolução magmática, (2) feldspato potássico que alcança $1,2 \mathrm{~cm}$ de comprimento, e em menor quantidade por (3) plagioclásio de até $1,4 \mathrm{~cm}$ de extensão. São rochas constituídas essencialmente por quartzo (48-49\%), ortoclásio (30$42 \%$ ) e plagioclásio (3-18\%). Biotita $(<2 \%)$, magnetita $(<1,5 \%)$, fluorita, titanita, zircão, monazita e rutilo ocorrem como acessórios, enquanto clorita, epídoto, sericita, caulinita, calcita e hematita como fases hidrotermais. A fluorita é representada por cristais anédricos, de granulação fina e que normalmente ocorre em paragênese com biotita e magnetita. A biotita forma cristais (sub)euédricos de granulação fina a média geralmente cloritizados. Pirita disseminada e com pequenas inclusões anédricas de calcopirita ainda pode ser encontrada. De acordo com Assis (2011) a colocação desse pórfiro teria instalado o sistema magmático-hidrotermal responsável pela gênese das mineralizações auríferas polimetálicas, do tipo epitermal, encontradas na região.

\section{DIQUES DE VULCÂNICAS MÁFICAS A FÉLSICAS}

Essas rochas intrudem em todas as unidades supracitadas. São individualizadas em três grupos petrográficos e geoquímicos distintos que ocorrem na forma de diques de direção preferencial N20-59E, com poucas dezenas de comprimento, mas que não ultrapassam os 10-15 m de largura (Fig. 7A).

O primeiro grupo é representado por rochas de tonalidade cinza escura, textura subofítica, raramente porfirítica, denotada por cristais de plagioclásio e raramente de allanita (Fig. 7B). O segundo individualiza-se pela coloração cinza-esverdeado, granulação fina e textura porfirítica representada por fenocristais de plagioclásio e quartzo biterminados (Fig. 7C) e, subordinadamente de piroxênio. $O$ terceiro grupo é ilustrado por rochas de coloração cinza-escuro a cinza-amarronado de matriz quartzo-feldspática com fenocristais euedrais e biterminados de até $1,5 \mathrm{~mm}$ de quartzo e plagioclásio (Figs. 7D e E).

ROCHAS SEDIMENTARES SILICICLÁSTICAS Uma sequência de arenito com níveis conglomeráticos recobrem todas as unidades anteriormente descritas, em extensos platôs que sustentam o relevo local. Em imagens ASTER e LANDSAT, formam alinhamentos positivos de direção NE-SW. São rochas de granulometria fina, com grãos subarredondados que formam camadas plano-paralelas de até $10 \mathrm{~cm}$ de espessura. Estratificação cruzada de médio a alto ângulo na base, com atitude N15W/40NE, e estratificação plano-paralela no topo, são estruturas comuns. Neste sentido, as rochas pertencentes a esta unidade possivelmente devem ser correlatas às da Unidade I da Formação Dardanelos, descrita por Souza et al. (2005), cuja deposição teria se processado em um sistema de rios entrelaçados, enquanto que os níveis conglomeráticos, com clastos graníticos e vulcânicos, são interpretados como formados em um sistema de leques aluviais.

\section{LITOGEOQUÍMICA}

Variação dos Elementos Maiores e Menores $\mathrm{O}$

PFU corresponde à unidade cujos valores de elementos maiores e menores apresentam maior homogeneidade, típicos de suítes pouco fracionadas. As SGR e SGN, no entanto, apresentam ampla dispersão nos dados, possivelmente um reflexo de que processos de fracionamento magmático atuaram mais efetivamente nessas unidades (Fig. 8).

De modo geral, o PFU é mais enriquecido em sílica $(75,6-76,2 \%)$ do que as SGR e SGN, que apresentam valores nos intervalos de $63,2-72,1 \%$ e $54,3-$ $66,1 \%$, respectivamente (Tab. 1). As razões $\mathrm{K}_{2} \mathrm{O} / \mathrm{Na}_{2} \mathrm{O}$ para o PFU, SGR e SGN variam de $1,49-1,66$; $0,66-$ 1,49 e $0,6-1,22$, respectivamente. As elevadas concentrações de plagioclásio e hornblenda nos granodioritos seriam os responsáveis pela maior concentração de $\mathrm{CaO}(3,7-7,3 \%)$ nos granodioritos, enquanto que a elevada quantidade de ortoclásio no PFU seria a causa das altas razões $\mathrm{K}_{2} \mathrm{O} / \mathrm{Na}_{2} \mathrm{O}$. O PFU apresenta os menores percentuais de $\mathrm{Fe}_{2} \mathrm{O}_{3}(1,5-1,7 \%), \mathrm{MgO}(0,09-0,23 \%)$ e $\mathrm{P}_{2} \mathrm{O}_{5}(0,02-0,04 \%)$, enquanto que as rochas granodioríticas exibem os menores valores de $\mathrm{K}_{2} \mathrm{O}(2,1-$ $4 \%)$, porém, maiores de $\mathrm{Fe}_{2} \mathrm{O}_{3}(3,8-6,1 \%), \mathrm{MgO}(1,3-$ $3,7 \%), \mathrm{TiO}_{2}(0,48-0,86 \%), \mathrm{P}_{2} \mathrm{O}_{5}(0,15-0,86 \%)$ e $\mathrm{MnO}$ $(0,05-0,23 \%)$ (Tab. 1 e Fig. 8). As concentrações dos elementos maiores na SGR situam-se frequentemente em posição intermediária entre as rochas da $\mathrm{SGN}$ e as do PFU. Hornblenda, biotita, titanita e apatita, comuns na SGN, mas ausentes e/ou acessórias nas demais suítes, seriam as responsáveis pelas variações observadas nesses valores. No entanto, as concentrações de $\mathrm{Al}_{2} \mathrm{O}_{3}$ mantiveram-se relativamente constantes entre as suítes analisadas: SGN (14,4-19\%), SGR $(13,4-14,4 \%)$ e PFU (11,7-11,9\%).

Os diagramas de Harker (Fig. 8) mostram que as rochas das suítes granítica e granodiorítica exibem tendências de variação coerentes com uma possível evolução por cristalização fracionada, enquanto que para o PFU, a pouca dispersão dos pontos, aponta para uma série pouco fracionada. Esses diagramas revelam que o comportamento dos óxidos para as SGR e SGN é normalmente inverso daquele observado para o quartzo-feldspato pórfiro, indicando a não cogeneticidade 

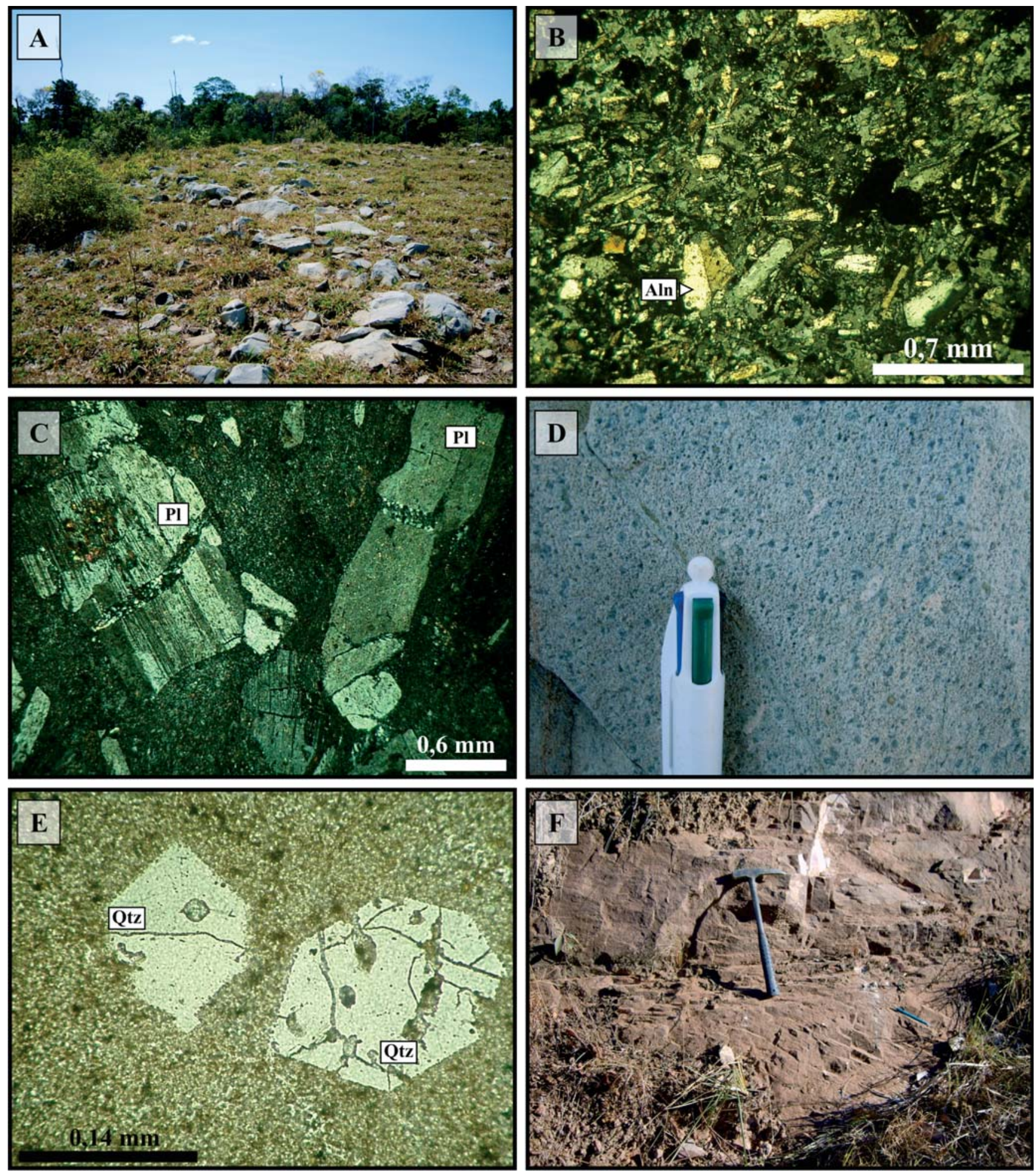

Figura 7 - (A) Diques máficos de pequena extensão, geralmente com poucos metros de largura e algumas dezenas de comprimento; Fotomicrografias de (B) Textura porfirítica representada por cristais de plagioclásio e allanita imersos em matriz fina subofítica em rocha de composição basáltica; (C) Andesito com fenocristais de plagioclásio (Pl) imersos em matriz afanítica; (D) Dacito com fenocristais de plagioclásio e piroxênio; (E) Fotomicrografia de quartzo (Qtz) biterminado em rocha dacítica; (F) Afloramento de arenito da sequência sedimentar de cobertura (Formação Dardanelos) com estratificação plano-paralela sotaposta por estratificação cruzada de alto ângulo. Fotomicrografias: $B-C=$ polarizadores cruzados; $E=$ luz natural. 
Rafael Rodrigues de Assis et al.
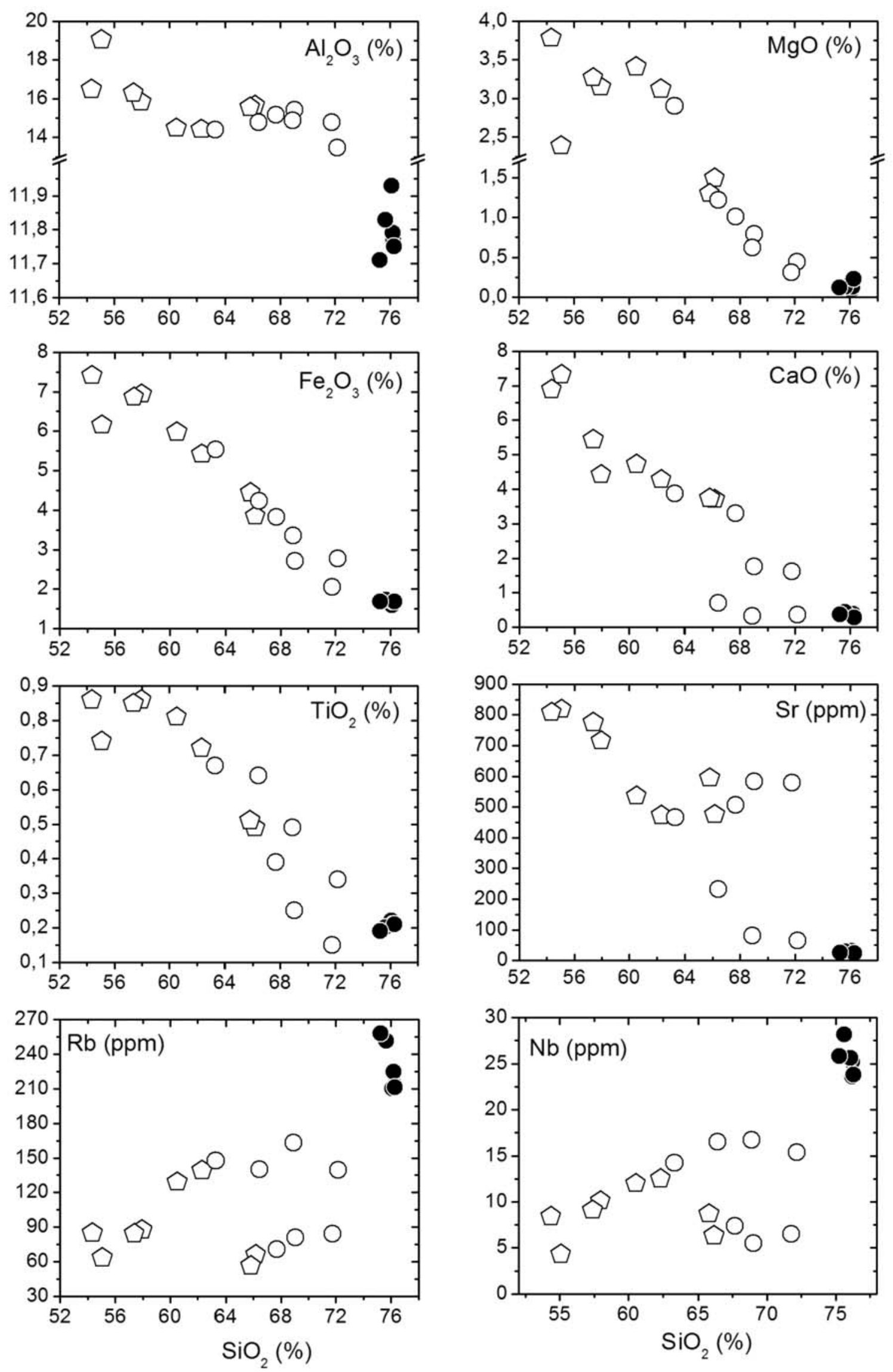

Pórfiro União do Norte $\bigcirc$ Suíte Granítica $\triangle$ Suíte Granodiorítica

Figura 8 - Diagramas de Harker para elementos maiores, menores e traço de rochas das suítes plutônicas da região de União do Norte. 
desta unidade com as demais. Entretanto, a sobreposição dos valores dos óxidos em função do aumento da sílica para as SGN e SGR indica que ambas correspondem a séries cogenéticas. Para o PFU, observam-se correlações positivas do $\mathrm{Al}_{2} \mathrm{O}_{3}, \mathrm{Fe}_{2} \mathrm{O}_{3}, \mathrm{MgO}$ e $\mathrm{TiO}_{2}$ com a sílica, enquanto que $\mathrm{CaO}$ apresenta relação inversa. Na SGN, exceto para o $\mathrm{K}_{2} \mathrm{O}$, todos os demais elementos apresentam relação inversa com o enriquecimento em sílica.

Os três grupos de vulcânicas individualizados são distinguidos pelas concentrações de sílica e álcalis (Fig. 9). O primeiro grupo, predominantemente na região de composição básica, exibe intervalos de $\mathrm{SiO}_{2}$ que variam de $47,7-49,2 \%$ e de $\mathrm{K}_{2} \mathrm{O}+\mathrm{Na}_{2} \mathrm{O}$ entre $4,8-5 \%$, típica de traquibasalto. O segundo grupo, no entanto, apresenta concentrações intermediárias de sílica $(53,2-57,8 \%)$ e álcalis $(3,9-6,2 \%)$, compatíveis com traquiandesito basáltico a andesito. E, finalmente, o terceiro grupo, de natureza ácida, é representado por valores $\mathrm{SiO}_{2}$ compreendidos entre $64,6-66,9 \%$ e de $\mathrm{K}_{2} \mathrm{O}+\mathrm{Na}_{2} \mathrm{O}$ entre 6,1-6,4\%, típico de dacitos.

VARIAÇÃO DOS ELEMENTOS-TRAÇO As SGR e SGN, respectivamente, apresentam os valores mais elevados de Ni (1,8-23,6 ppm e 3,6-36,1 ppm), Co (2,3$17,3 \mathrm{ppm}$ e 7,4-27,3 ppm), Sr (65,9-583,5 ppm e 473$818,1 \mathrm{ppm})$ e $\mathrm{Ba}(502-1.437 \mathrm{ppm}$ e $774-1.398 \mathrm{ppm})$, enquanto que os de $\mathrm{Hf}(10,9-12,8 \mathrm{ppm}), \mathrm{Nb}(23,6-28,2$ ppm), Zn (60-171 ppm) e Rb (210,4-257,8 ppm) são mais elevados na unidade subvulcânica.

A exemplo do observado para os elementos maiores e menores, o comportamento de alguns elementos-traço das SGN e SGR é o inverso daquele obtido para o PFU (Fig. 8). Adicionalmente, são observados aumentos dos teores de $\mathrm{Sr}, \mathrm{Ba}$ e $\mathrm{Zr}$ com o aumento da $\mathrm{SiO}_{2}$ no $\mathrm{PFU}$, enquanto que nas demais suítes os teores de $\mathrm{Sr}$ e $\mathrm{Zr}$ diminuem com o enriquecimento em sílica. As concentrações de $\mathrm{Ta}$ e $\mathrm{Rb}$ aumentam com o enriquecimento em sílica nas SGN e SGR, ao passo que Rb, Y, Nb e Ta são empobrecidos no PFU (Fig. 8). Neste contexto, o aumento do $\mathrm{Sr}$ e Ba no quartzo-feldspato pórfiro sugere que o fracionamento magmático, a exemplo do sugerido anteriormente, não teria sido efetivo.

Os padrões de elementos terra raras (ETR) e de elementos-traço, normalizados pelo manto primitivo (McDonough \& Sun 1995) (Fig. 10), mostram que a SGR é ligeiramente mais enriquecida em elementos-traço quando comparada às demais suítes (Figs. 10A,

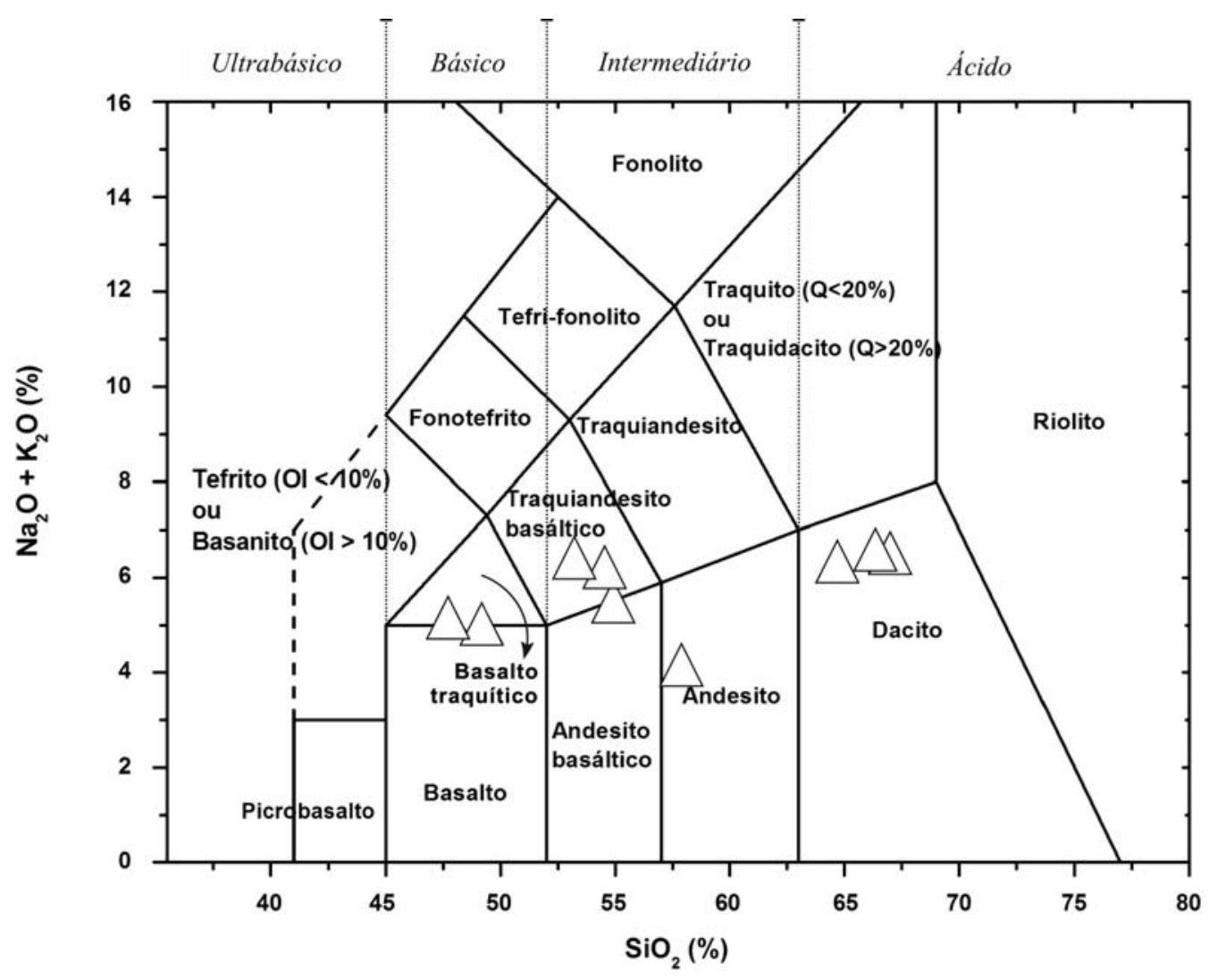

Figura 9 - Diagrama de TAS (total álcali-silica, Le Bas et al. 1986), com as amostras dos diques de vulcânicas da área de União do Norte. Pelo diagrama nota-se a ocorrência de três grupos principais, com predominância daqueles de composição intermediária à ácida. 
C, E). Todas as intrusões exibem anomalias negativas de Nb, K e Ti. Entretanto, a SGN e o PFU apresentam pronunciadas anomalias positivas de $\mathrm{Pb}$, ausentes na SGR. Acentuadas anomalias negativas de Sr são observadas no PFU e na SGR, enquanto que na SGR, essa anomalia é praticamente inexistente, exceto para o tonalito. As SGN e SGR mostram anomalias positivas de $\mathrm{Ba}$, enquanto que o PFU exibe anomalias negativas.

O comportamento dos ETR nas três unidades plutônicas é caracterizado pelo enriquecimento de ETRL em relação aos ETRP, embora esse enriquecimento seja mais pronunciado na $\mathrm{SGR}\left(\mathrm{La}_{\mathrm{n}} / \mathrm{Yb}_{\mathrm{n}} \approx 7,4-\right.$ $26,2)$ e $\mathrm{SGN}\left(\mathrm{La}_{\mathrm{n}} / \mathrm{Yb}_{\mathrm{n}} \approx 9,7-26,6\right)$, quando comparados ao $\mathrm{PFU}\left(\mathrm{La}_{\mathrm{n}} / \mathrm{Yb}_{\mathrm{n}} \approx 7,2-10,9\right)$. Esses resultados sugerem que o fracionamento magmático teria sido mais efetivo nas duas primeiras suítes, ou então da participação de uma fonte pobre em ETRP. Entretanto, a primeira hipótese é reforçada pela grande dispersão dos valores de elementos maiores e traço em relação ao índice de diferenciação ígnea (Fig. 8). Em adicional, nota-se que a Suíte Granodiorítica apresenta valores ligeiramente mais elevados para os ETR intermediários (e.g. Gd e $\mathrm{Tb}$ ) do que para os ETRP. Esse comportamento pode ser decorrente da ocorrência de hornblenda, titanita e apatita que por apresentarem elevado coeficiente de partição, contribuem, em magmas félsicos no enriquecimento de ETRL, a exemplo do Gd e Tb (Rollinson 1993). A maior diferença observada, no entanto, é
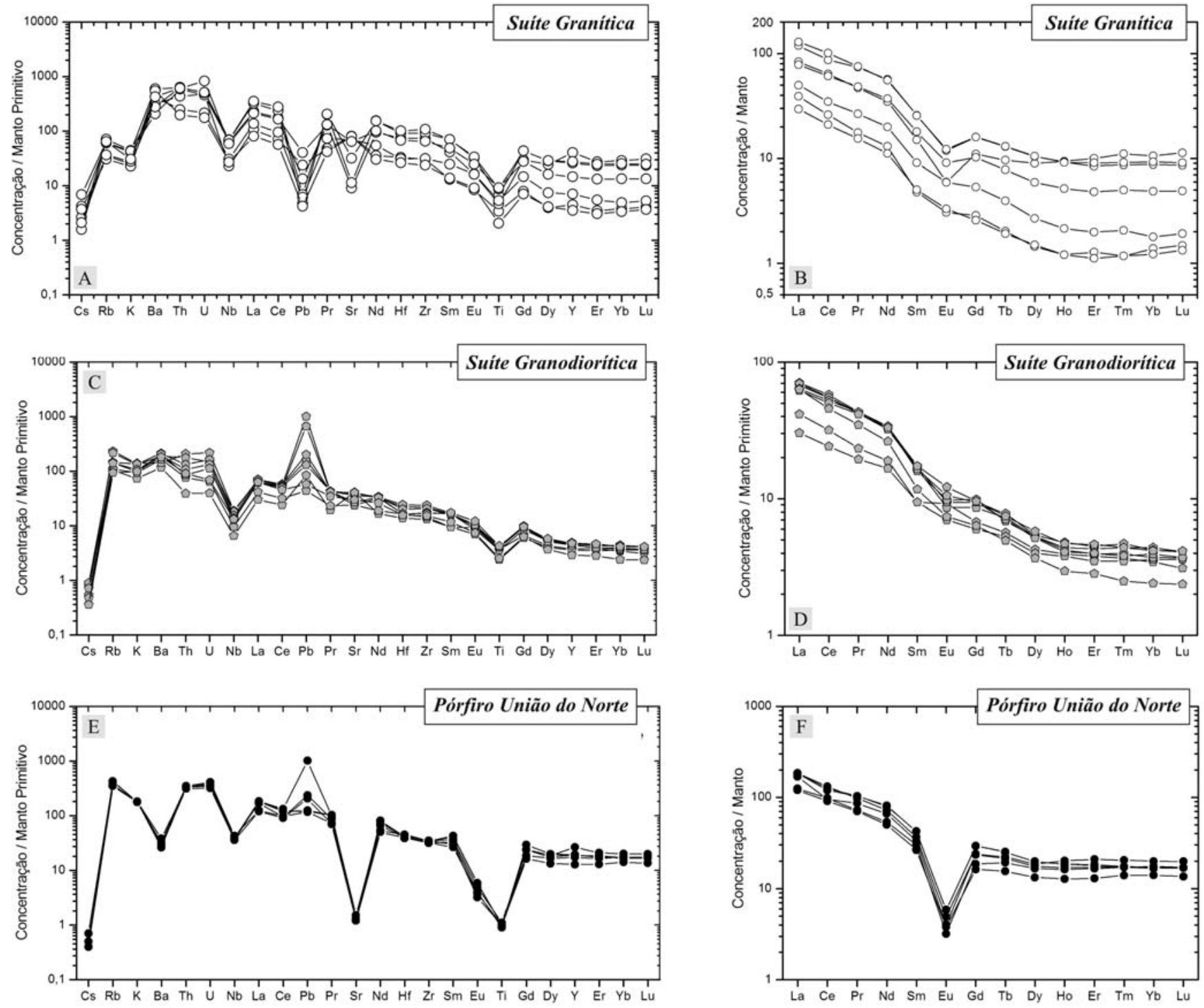

Figura 10 - Padrão de distribuição dos elementos terras raras e traço, normalizados pelo manto primitivo (McDonough \& Sun 1995), para as rochas das suítes: (A-B) granítica; (C-D) granodiorítica e (E-F) Pórfiro União do Norte. 
a forte anomalia negativa de Eu no Pórfiro União do Norte $\left(0,13<\mathrm{Eu} / \mathrm{Eu}^{*}<0,18\right)$. Essa anomalia é pouco pronunciada na Suíte Granítica $\left(0,46<\mathrm{Eu} / \mathrm{Eu}^{*}<0,87\right)$ e praticamente ausente na Suíte Granodiorítica $(0,68<$ $\left.\mathrm{Eu} / \mathrm{Eu}^{*}<1,14\right)$. A proeminente anomalia negativa de Eu no PFU pode indicar que o plagioclásio foi extraído do magma durante a cristalização fracionada ou ter permanecido como resíduo na fonte durante a fusão parcial. $\mathrm{O}$ enriquecimento em $\mathrm{K}_{2} \mathrm{O}$ e $\mathrm{Ba}$ (elementos incompatíveis) em função da sílica, é possível que a anomalia negativa de Eu deva ter sido função da remoção de plagioclásio na evolução magmática do PFU.

$\mathrm{O}$ padrão de elementos-traço e de ETR, das amostras dos diques vulcânicos, normalizados pelo manto primitivo (McDonough \& Sun 1995) novamente mostram assinaturas geoquímicas distintas para os três grupos individualizados (Fig. 11A). De modo geral, os dacitos e traquiandesitos basálticos são levemente mais enriquecidos em elementos-traço em relação aos demais diques. Anomalias negativas de $\mathrm{K}, \mathrm{Th}, \mathrm{Nb}, \mathrm{Pb}$ e Ti são comuns em todos os grupos. Tório e Ti podem exibir suaves anomalias positivas em algumas amostras do segundo grupo, enquanto que os basaltos e uma amostra do dacito apresentam fortes a moderadas anomalias positivas de $\mathrm{Pb}$ (Fig. 11A). O traquiandesito basáltico mostra anomalias negativas mais pronunciadas de $\mathrm{Pb}(3,27-12,59 \mathrm{ppm})$ e $\mathrm{K}(1,49-1,98 \%)$, enquanto que nos basaltos e dacitos, observa-se anomalias negativas mais proeminentes de $\mathrm{Nb}(4,25-12,46 \mathrm{ppm})$ e $\mathrm{Ti}(0,32-0,37 \%)$, respectivamente. Os andesitos exibem anomalias negativas pouco pronunciadas para $\mathrm{K}, \mathrm{Ti}$, $\mathrm{Th}, \mathrm{Nb}, \mathrm{Pb}$, enquanto enriquecimento fraco a moderado é observado para o Sr. Esses valores podem variar de 24 a 129 ppm para as rochas dacíticas e de 82 a 146 para o traquiandesito basáltico. O padrão de distribuição dos elementos-traço da suíte granodiorítica (Fig. 10C) é similar ao das rochas vulcânicas, com concentração maior de LILE em relação aos HFSE, além de marcantes anomalias negativas de $\mathrm{Nb}$ e Ti. Anomalias negativas de $\mathrm{Nb}, \mathrm{Pb}$ e Ti, são típicas de rochas com
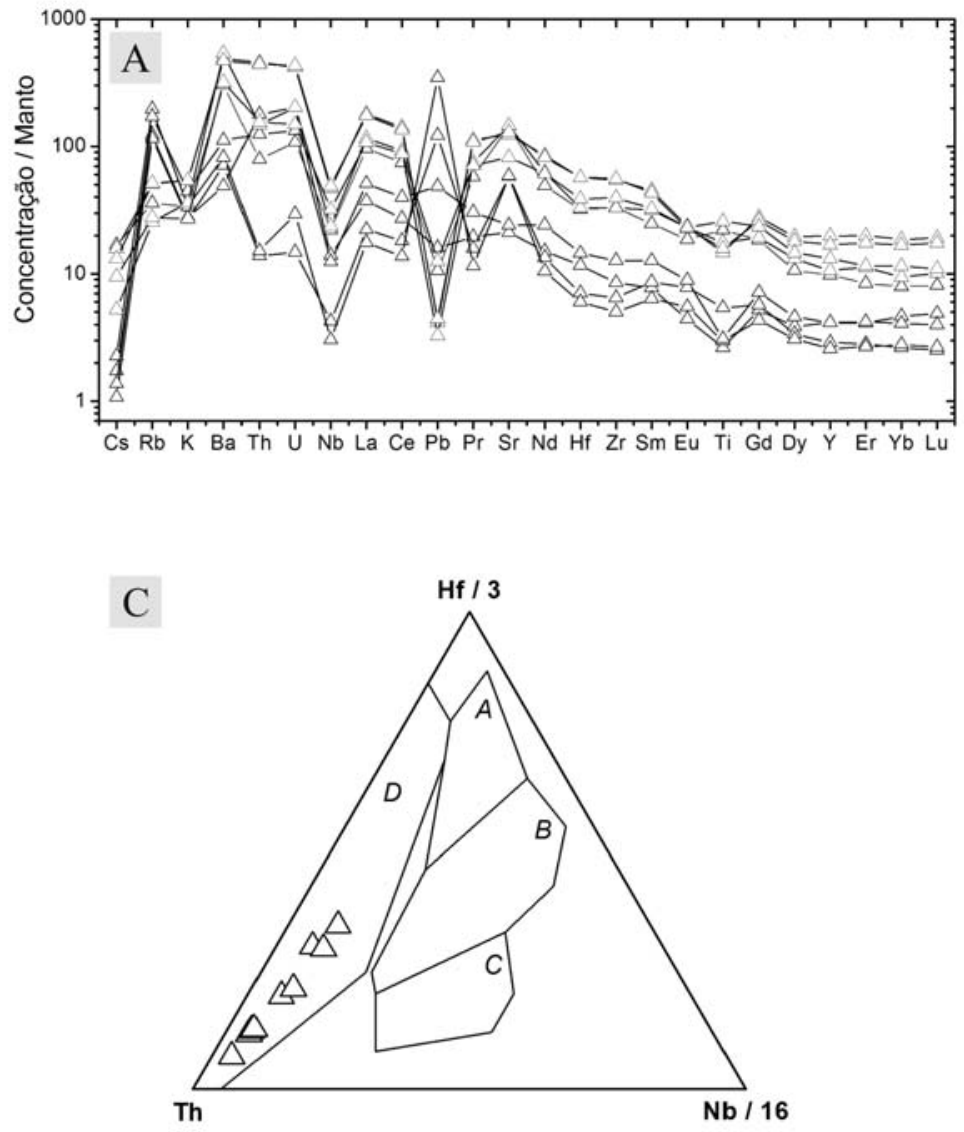
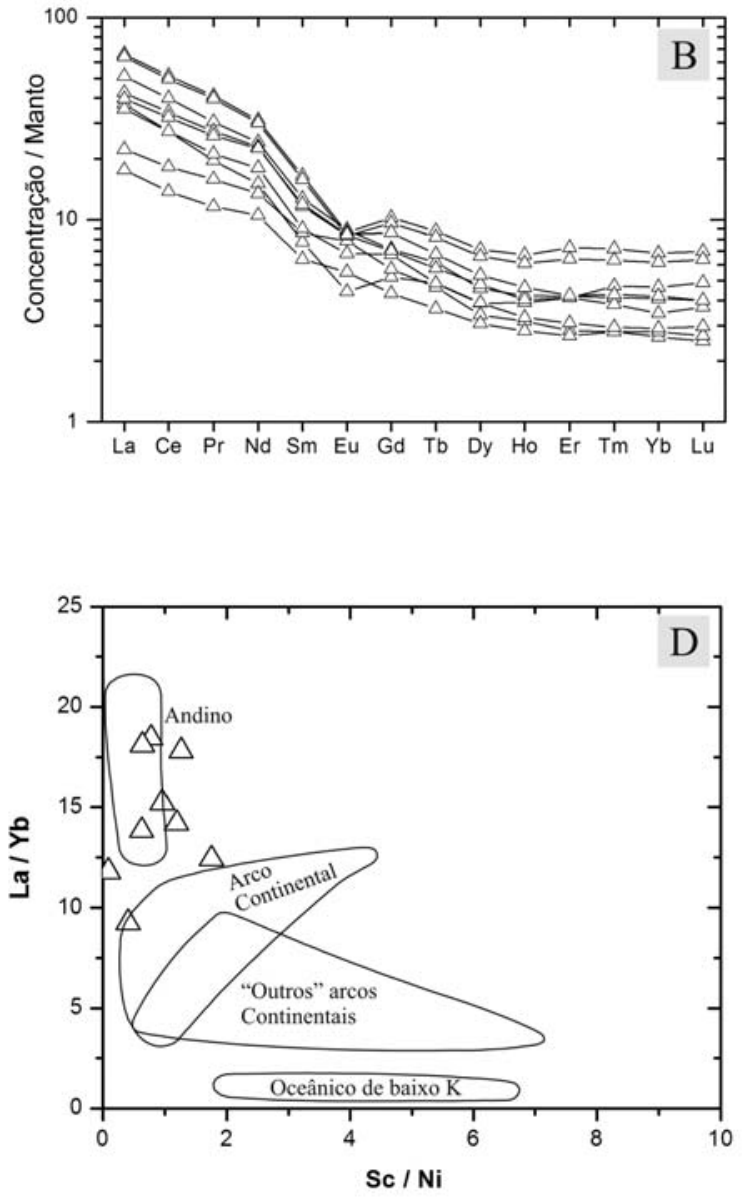

Figura 11 - Geoquímica das rochas vulcânicas da região de União do Norte. Diagramas de dispersão normalizados pelo manto primordial de McDonough \& Sun (1995): (A) Diagrama multielementar; (B) padrões de distribuição dos ETR; Diagramas de discriminação tectônica segundo (C) Wood (1980), (D) Cabanis \& Lecolle (1989). Campos: A: N-MORB, B: E-MORB, C: basaltos alcalinos, D: basaltos de margens destrutivas. 
fonte mantélica, a exemplo daquelas originadas em arcos vulcânicos (Chandrasekharam et al. 2009, Wernick 2004, Yang et al. 2008).

De modo geral, os ETR apresentam um padrão moderadamente fracionado e homogêneo $\left(\mathrm{La}_{\mathrm{n}} / \mathrm{Yb}_{\mathrm{n}} \approx\right.$ 6,59-12,8). Os dacitos são mais enriquecidos em ETR, além de mostrarem anomalias de $\mathrm{Eu}\left(0,64<\mathrm{Eu} / \mathrm{Eu}^{*}<\right.$ $0,89)$ mais pronunciadas. Os andesitos, traquiandesitos basálticos e basaltos exibem razões Eu/Eu* compreendidas entre 0,$68 ; 0,82-0,89$ e 1,03-1,09, respectivamente. Portanto, os dacitos, com as menores razões $\mathrm{Eu} / \mathrm{Eu}^{*}$, seriam aqueles em que o fracionamento do plagioclásio teria sido mais acentuado, seguido dos basaltos, com fracionamento pouco efetivo, devido à ausência de anomalias negativas de Eu (Fig. 11B).

\section{CLASSIFICAÇÕES TECTONO-MAGMÁTICAS Os}

dados obtidos sugerem que as suítes plutônicas da região de União do Norte representam um magmatismo cálcio-alcalino a alcalino de alto K (Fig. 11). Com base no Índice de Wright (IW*), observa-se que as amostras da SGN $\left(1,5<\mathrm{IW}^{*}<2,1\right)$ incidem no campo dos granitoides cálcio-alcalinos, sendo que as da SGR $(2,1$ $\left.<\mathrm{IW}^{*}<3,7\right)$ também se enquadram naquelas dos granitoides alcalinos, enquanto que as do PFU $\left(3,2<\mathrm{IW}^{*}\right.$ $<3,6$ ), inserem-se totalmente no campo dos granitos alcalinos. As amostras da unidade subvulcânica são aquelas com as menores relações $\mathrm{MgO}: \mathrm{FeO}^{\mathrm{t}}$ e maior concentração de $\mathrm{Na}_{2} \mathrm{O}+\mathrm{K}_{2} \mathrm{O}$ (Fig. 11A). A SGN exibe os maiores valores de $\mathrm{FeO}^{\mathrm{t}}$, reflexo de sua natureza mais primitiva e da presença de hornblenda e magnetita como fases acessórias. A SGN apresenta característica essencialmente metaluminosa, enquanto que o PFU exibe caráter metaluminoso a levemente peraluminoso e a SGR levemente peraluminoso (Figs. 11A a C). Os elevados teores de $\mathrm{K}_{2} \mathrm{O}$ do PFU seriam os responsáveis pelo ASI da unidade estar próximo à unidade. Considerando a classificação proposta por Frost et al. (2001), observa-se que a SGN é magnesiana, enquanto o quartzo-feldspato pórfiro, com elevadas razões $\mathrm{FeO}^{t} /$ ( $\left.\mathrm{FeO}^{\mathrm{t}}+\mathrm{MgO}\right)$, compreendidas entre $0,86-0,94$, é ferroso (Fig. 11D). As rochas da SGR exibem assinatura essencialmente ferrosa, porém, com leve tendência em direção ao campo dos granitoides ferrosos. Com base no índice de alcalinidade modificado (MALI), as amostras do PFU são álcali-cálcicas, enquanto que as demais suítes são cálcio-alcalinas a álcali-cálcicas (Fig. 11E). Devido à cristalização pervasiva de ortoclásio hidrotermal, observado tanto em campo quanto em lâmina, algumas amostras da SGR, no entanto, apresentam características de magmatismo alcalino e shoshonítico (Figs. 11B e D). As rochas vulcânicas representam um magmatismo cálcio-alcalino de médio a alto $\mathrm{K}$, metaluminoso a fracamente peraluminoso (Fig. 11).
AMBIÊNCIA TECTÔNICA Nos diagramas de discriminação tectônica de Pearce et al. (1984), as rochas das SGR e SGN apresentam fortes afinidades com granitoides de arcos vulcânicos, embora parte da SGR também se encontre em domínio pós-colisional (Figs. $12 \mathrm{~A}$ e B). Por outro lado, o PFU está intrinsecamente relacionado a magmas graníticos gerados em ambiente pós-colisional. Observa-se também um trend geoquímico que poderia representar a evolução geodinâmica do ambiente, desde arcos vulcânicos, representados pelos granodioritos e granitos, até o encerramento do evento orogenético, em plataforma mais estável, com a colocação de rochas mais evoluídas (PFU). Essa tendência evolutiva sustenta-se pelas relações de campo que apontam que a SGN é intrusiva na SGR, enquanto que o PFU intrude todas as demais. A partir dos diagramas de Whalen et al. (1987), observa-se que as amostras do PFU caem no campo dos granitoides intraplaca (tipo A), enquanto aquelas das SGN e SGR exibem afinidades geoquímicas com granitos orogênicos do tipo I (Figs. 12C a E). As amostras do PFU, por exibirem afinidades com granitos do tipo $\mathrm{A}$, foram plotadas nos diagramas de ambiente geodinâmico propostos por Eby (1992). A partir das concentrações de Al, Ga, Y e Nb (Fig. 12F), observa-se que o quartzo-feldspato pórfiro se enquadra no campo dos granitoides cuja fonte teriam sido magmas formados em ambientes pós-colisionais, denotando, portanto, fonte eminentemente crustal (granitos tipo A2).

Os diagramas de discriminação tectônica para os diques de vulcânicas da região de União do Norte definem um típico magmatismo de arco vulcânico continental, onde as elevadas razões $\mathrm{La} / \mathrm{Yb}$, normalmente entre 9,26 e 18,44, sugerem vulcanismo do tipo andino (Figs. 13C e D).

Geoquímica da Unidade Vulcanoclástica Os sedimentos da Unidade Vulcanoclástica apresentam elevados teores de $\mathrm{CaO}(0,31-2,22 \%), \mathrm{Na}_{2} \mathrm{O}(0,97-4,7 \%)$, $\mathrm{K}_{2} \mathrm{O}(3,5-5,1 \%), \mathrm{SiO}_{2}(71,7-81,5 \%)$ e $\mathrm{Fe}_{2} \mathrm{O}_{3}+\mathrm{MgO}$ $(2,1-5,4 \%)$, contudo, baixas de $\mathrm{TiO}_{2}(0,3-0,41 \%)$ (Tab. 1). Observa-se grande homogeneidade em relação às concentrações de elementos-traço, exceto para o $\mathrm{Cu}$ (1,3-6,1 ppm), Zn (14-54 ppm) e Co (2,3-9,9 ppm), que exibem as maiores variações. Essas rochas mostram elevadas concentrações de $\mathrm{Ba}$ (621-868 ppm), $\mathrm{Rb}$ (81,5-121,6 ppm) e Zr (139-265,3 ppm), assim como baixos de $\mathrm{Sb}(0,1-2,0 \mathrm{ppm})$ e Ta $(0,4-0,6 \mathrm{ppm})$. Em comparação com a média dos condritos de McDonough \& Sun (1995), observam-se fortes anomalias negativas de P-Cs, V-Cr-Ni, pequenas anomalias negativas de Ti e Y, leve empobrecimento em Sc (Fig. 14A), anomalias positivas de $\mathrm{U}$ e $\mathrm{Ba}$, e enriquecimento em $\mathrm{K}, \mathrm{Rb}$, Ta, Hf, Zr e Th. 

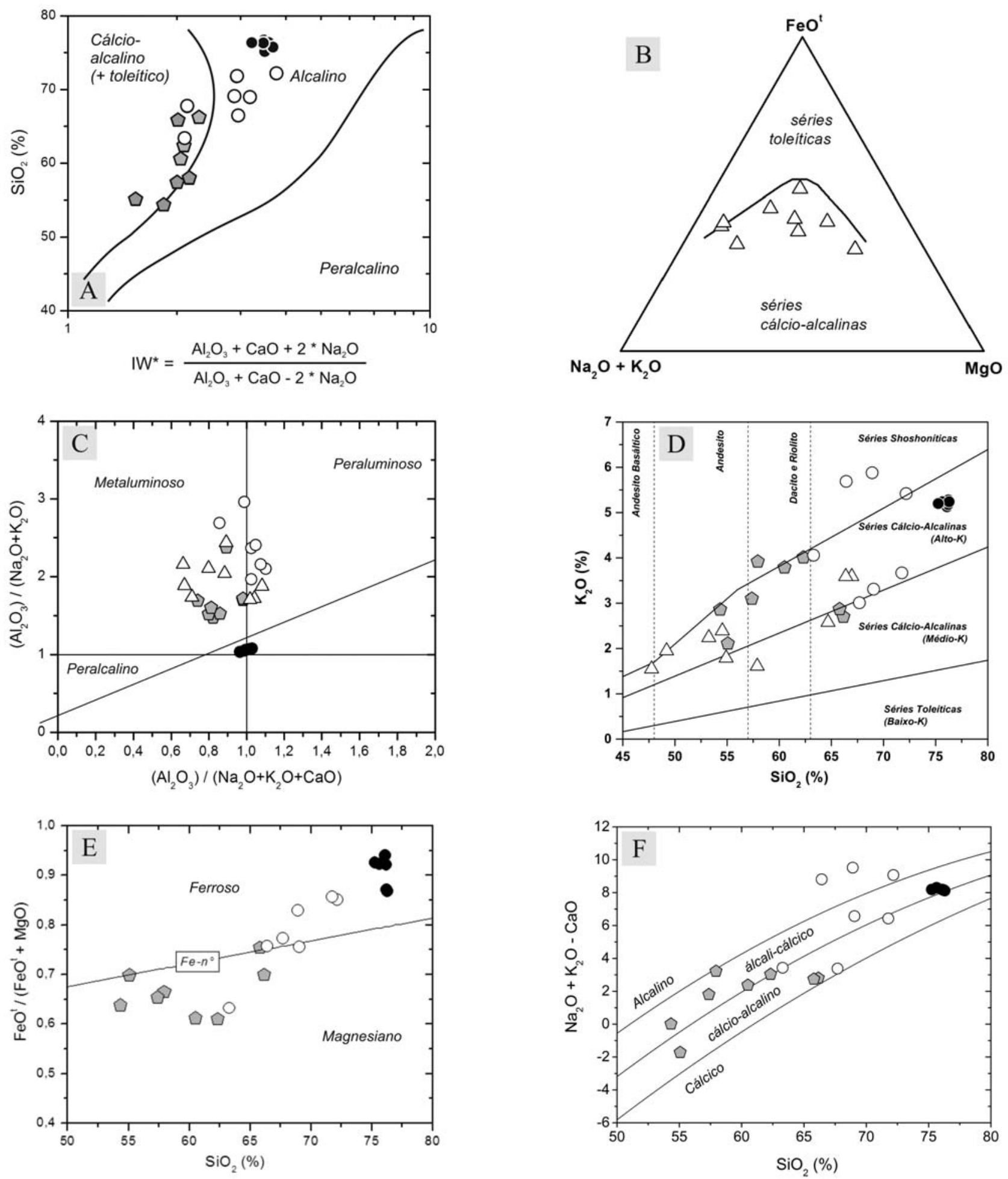

Suíte Granodiorítica $\bigcirc$ Suíte Granítica

Pórfiro União do Norte $\triangle$ Diques de vulcânicas máficas a félsicas

Figura 12 - Diagramas de classificação geoquímica das suítes de rochas plutônicas e dos diques máficos a félsicos da região de União do Norte, com base em elementos maiores: (A) diagrama AFM (Irvine \& Baragar 1971); (B) $\mathrm{K}_{2} \mathrm{O}$ versus. $\mathrm{SiO}_{2}$ (Le Maitre et al. 1989); (C) MALI; (D) A/CNK versus A/NK (Maniar \& Piccoli, 1989) e (E) Número de Ferro (Frost et al. 2001). 

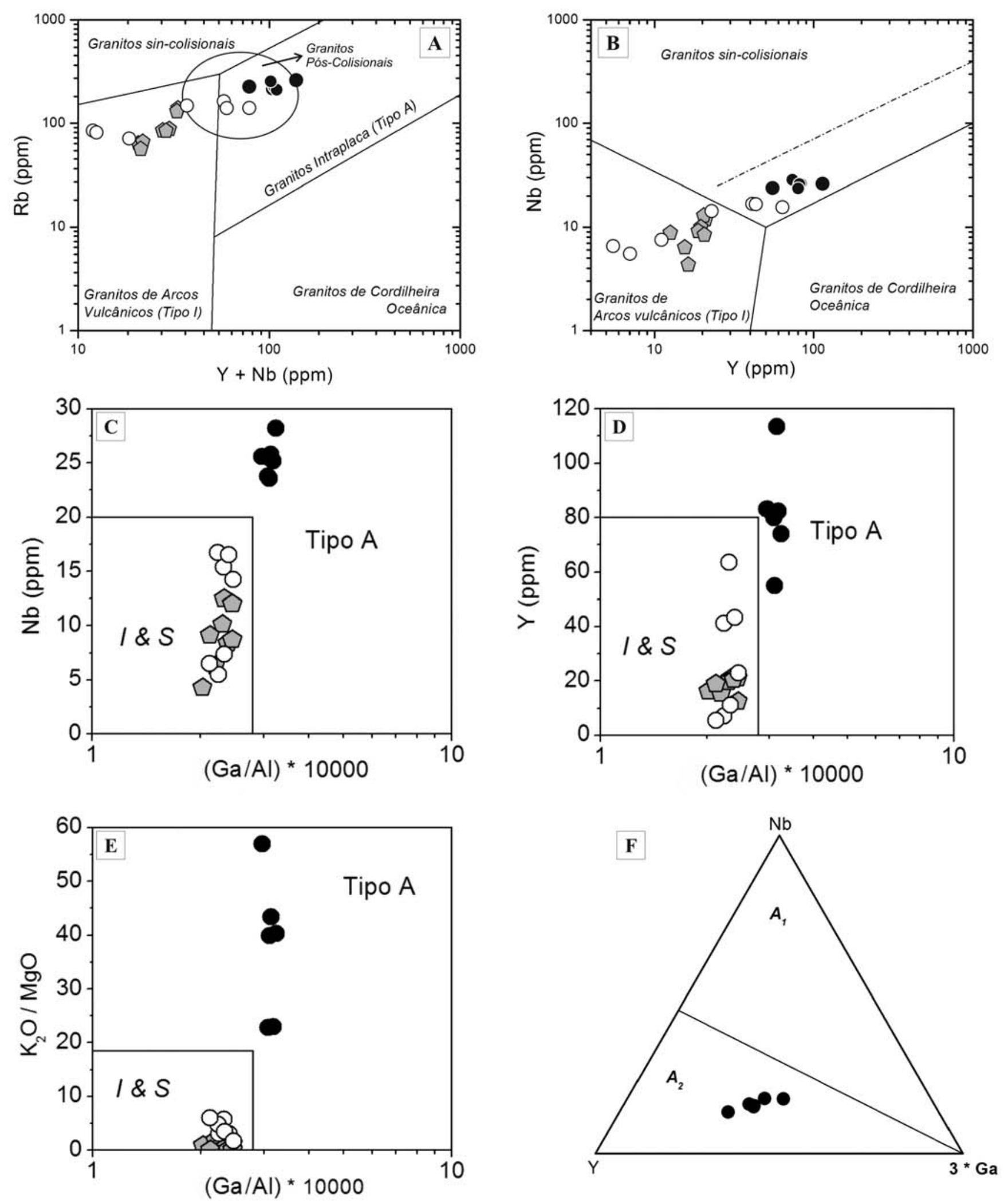

Suíte Granodiorítica $\bigcirc$ Suíte sieno-monzogranítica

Pórfiro União do Norte

Figura 13 - Diagramas de discriminação tectônica para as suítes de rochas graníticas da região de União do Norte: (A) Rb versus $\mathrm{Y}+\mathrm{Nb}$; (B) Nb versus Y; (Pearce et al., 1984); Diagramas propostos por Whalen et al. (1987): $1000 *(\mathrm{Ga} / \mathrm{Al})$ versus (C) Nb; (D) Y; (E) K_O/MgO; (F) Ternário $3{ }^{*} \mathrm{Ga}: \mathrm{Nb}: Y$ de Eby (1992) para distinção de granitoides do tipo A. 

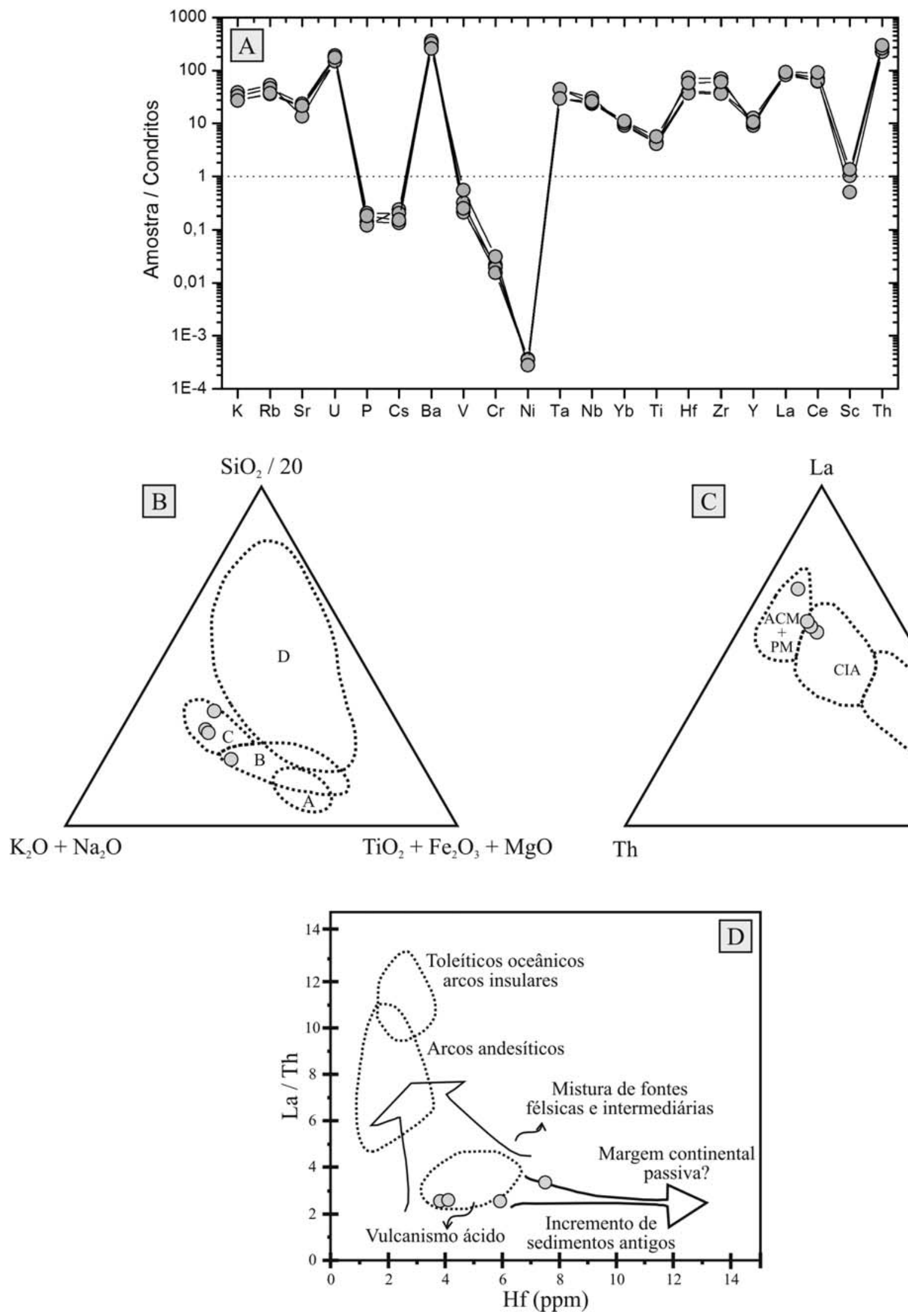

Figura 14 - Diagramas geoquímicos para as rochas da Unidade Vulcanoclástica: (A) Multielementar normalizado pelos condritos de McDonough \& Sun (1995); Proveniência sedimentar siliciclástica segundo: (B) Kroomemberg (1994); (C) Bhatia \& Crook (1986); (D) Floyd \& Leveridge (1987). Campos: A-OIA: arco insular oceânico, B-CIA: arco insular continental, C-ACM: margem continental ativa, D-PM: margem passiva. 
Os teores mais elevados de sílica e álcalis $(6,08-$ $8,4 \%$ ), assim como as elevadas concentrações de La (19,3-21,9 ppm), baixas de Th (6,5-8,6 ppm) e Sc (3,0$8,0 \mathrm{ppm})$, sugerem que a sedimentação da Unidade Vulcanoclástica teria ocorrido em ambiente de margens continentais ativas (Figs. 14B e C). As baixas razões $\mathrm{Ta} / \mathrm{Th}(2,54$ a 3,35) e as pequenas concentrações de Hf (3,8 a 7,5 ppm) são típicas de regiões de vulcanismo ácido com interação entre fontes intermediárias e félsicas (Fig. 14D).

DISCUSSÃO Em mapeamento realizado por Moreton \& Martins (2005) e Souza et al. (2005), a região de União do Norte é cartografada como pertencente à Suíte Intrusiva Matupá (1872 \pm 12 Ma; Moura 1998), e constituída por clinopiroxênio-hornblenda monzogranito e clinopiroxênio-hornblenda monzodiorito magnético (fácies 3), além de biotita granito e monzogranito com microgranitos e granófiros subordinados (fácies 4). Esse trabalho, no entanto, define para essa região e em ordem temporal, uma unidade vulcanoclástica, três suítes plutônicas, uma de composição granodiorítica, outra granítica e uma terceira com subvulcânicas epizonais, com álcali-feldspato granito porfirítico a monzogranito porfirítico. Diques de vulcânicas máficas a félsicas truncam todas as unidades supracitadas. Todas essas unidades ainda são recobertas pelos sedimentos arenáceos da Formação Dardanelos (Grupo Caiabis).

Os dados aqui apresentados sugerem que a erosão de antigos centros vulcânicos originou sedimentos ricos em fragmentos de cristais (e.g. quartzo e feldspato) e líticos (essencialmente de vulcânicas intermediárias). A ocorrência frequente de estruturas sedimentares de fluxo, tais como estratificações plano-paralelas e cruzadas, assim como a ausência de estruturas piroclásticas (e.g. fiammes) remeteria a uma origem epiclástica para os sedimentos da Unidade Vulcanoclástica. A imaturidade química (feldspato pouco alterado) e textural (relativa variação morfológica) dos sedimentos, moderado grau de seleção e baixo arredondamento, corroboram para um curto transporte, baixo retrabalhamento e deposição proximal à área fonte. Os estudos de proveniência sedimentar clástica (Assis, 2011) e geoquímicos indicam que zonas vulcânicas continentais teriam correspondido ao ambiente de geração desses sedimentos, com deposição em região de clima árido e elevado gradiente topográfico. Os diagramas de proveniência tectônica baseados em elementos maiores e menores apontam para uma deposição em ambiente de margem continental ativa, onde arcos vulcânicos e rochas ígneas félsicas teriam sido as fontes principais. A elevada quantidade de fragmentos de vulcânicas intermediárias (e.g. dacíticas, riodacíticas), além das menores concentrações de vulcânicas básicas e plutônicas félsicas (e.g. granitos), constitui a evidência mais clara de que arcos vulcânicos intermediários a félsicos teriam representado a área fonte dos sedimentos desta unidade. As baixas concentrações de Sc (3-8 ppm), $\mathrm{Cr}_{2} \mathrm{O}_{3}(0,01-0,02 \%)$ e Co (2,3-9,9 ppm), intermediárias de La (19,3 a 21,9 ppm), Th (6,5-8,6 ppm) e Hf (3,87,5 ppm), porém, altas de $\mathrm{Zr}$ (139 a $235 \mathrm{ppm})$, razões $\mathrm{Co} / \mathrm{Th}$ próximas a $1(0,35<\mathrm{Co} / \mathrm{Th}<1,5)$, baixas a intermediárias razões $\mathrm{La} / \mathrm{Sc}(2,73<\mathrm{La} / \mathrm{Sc}<7,26)$ e baixas de $\mathrm{La} / \mathrm{Th}(2,54<\mathrm{La} / \mathrm{Th}<3,35)$, sugerem mistura entre componentes félsicos e intermediários. Logo, a deposição desta unidade teria ocorrido em uma bacia instalada em ambiente retroarco do tipo foreland (retroarc foreland basin), que segundo Nichols (1999), são representadas dominantemente por ambientes fluviais, costeiros e de águas rasas, cuja principal fonte sedimentar corresponde ao cinturão montanhoso e ao arco vulcânico instalado em suas proximidades.

Intrusivas na Unidade Vulcanoclástica estão as rochas álcali-cálcicas a cálcio-alcalinas, metaluminosas, de alto $\mathrm{K}$ e magnesianas da SGN, cujo padrão fortemente fracionado em ETR $\left(\mathrm{La}_{\mathrm{n}} / \mathrm{Yb}_{\mathrm{n}} \approx 9,7-26,6\right)$ é indicativo de evolução controlada por fracionamento magmático. Essa característica, a exemplo das anomalias de Eu pouco pronunciadas, podem refletir a cristalização da apatita, titanita e hornblenda, que segundo Rollinson (1993), Deer et al. (2000) e Wernick (2004), tendem a incorporar os ETRL em detrimento dos ETRP. Adicionalmente, as pronunciadas anomalias negativas de $\mathrm{Nb}$ e Ti, assim como as baixas concentrações de Ta, $\mathrm{Y}$ e $\mathrm{Nb}$ apontam para granitos do tipo I, originados em ambiente de arcos vulcânicos. A SGR por sua vez, é mais jovem ou contemporânea a anterior, e mostra texturas (micro)gráfica, porfirítica e rapakivi que indicam alojamento em nível crustal mais raso e em contexto geotectônico mais estável, quando comprado à SGN. Também representa magmatismo cálcio-alcalino a álcali-cálcico, peraluminoso, de alto $\mathrm{K}$, magnesiano a levemente ferroso e de padrão fortemente fracionado, com razões $(\mathrm{La} / \mathrm{Lu})_{\mathrm{N}}$ de até 28,06 . Os padrões de elementos-traço, as anomalias de Eu mais pronunciadas e elevadas concentrações de LILE, podem indicar tanto a extração de fases ricas em ETRL (e.g. plagioclásio, hornblenda, apatita) quanto de processos de contaminação crustal, ou ambos. A inexistência de dados geocronológicos para as SGN e SGR impossibilita correlacioná-las de forma mais precisa às inúmeras manifestações plutônicas da PAAF. Entretanto, as relações de campo, características petrográficas (e.g. composição modal e fases acessórias) e litogeoquímicas (e.g. distribuição dos elementos maiores e traço, cogeneticidade e afinidades geoquímicas) sugerem que essas rochas possam ser equivalentes às da Suíte Intrusiva Matupá, de idade 
$1872 \pm 12 \mathrm{Ma}$ (Moura \& Botelho 1992, Moura 1998, Souza et al. 2005). Entretanto, as diferenças existentes nos diagramas de ambiência tectônica, observadas entre essas unidades, estariam relacionadas ao enriquecimento em elementos-traço via cristalização fracionada a partir da fusão de pequenas quantidades do manto empobrecido, tal como discutido por Pearce (1986). Essa hipótese apoia-se tanto no comportamento dos elementos nos diagramas de Harker quanto pelo comportamento dos ETR.

$\mathrm{O}$ alojamento de corpos mais tardios e de natureza subvulcânica é representada pelo PFU. Texturas porfiríticas, micrográficas e a elevada quantidade de veios e sistema de veios de quartzo nas imediações de seus contatos, seriam indícios de que a unidade teria se cristalizado e se saturado em fluidos em nível crustal relativamente raso. Diferentemente dos casos anteriores, o PFU representa um magmatismo alcalino de alto K, meta- a peraluminoso e ferroso. Também se distingue das demais pela homogeneidade dos dados geoquímicos, pelas altas concentrações de sílica $(>$ $76 \%)$ e $\mathrm{K}_{2} \mathrm{O}(>5 \%)$, baixas de $\mathrm{CaO}(0,2-0,4 \%)$, pelo enriquecimento em HFSE e metais de transição, pela forte anomalia negativa de $\mathrm{Eu}\left(0,13<\mathrm{Eu} / \mathrm{Eu}^{*}, 0,18\right)$ e pelas baixas razões $(\mathrm{La} / \mathrm{Lu})_{\mathrm{N}}$ (entre 7,2-10,9), que juntas são diagnósticas de um magma ácido e fortemente diferenciado. A relação direta entre $\mathrm{Al}_{2} \mathrm{O}_{3}$ e sílica seria indicativa da cristalização de fases sem $\mathrm{Al}_{2} \mathrm{O}_{3}$ e/ou com baixa concentração de sílica (e.g. fluorita, zircão, titanita, biotita), ou ainda, de processos de assimilação crustal. Embora não frequente, fragmentos da Unidade Vulcanoclástica estão presentes em alguns afloramentos do quartzo-feldspato pórfiro, assim como reentrâncias irregulares deste granito subvulcânico na unidade sedimentar. Essas relações poderiam indicar a interação do magma fonte do PFU com as sedimentares vulcanoclásticas e, portanto, incorporação de alumina e LILE.

Como observado nos diagramas de discriminação tectônica, a unidade subvulcânica exibe forte afinidade com as séries graníticas do tipo A, em oposição às suítes anteriores (granitos tipo I). Entretanto, é válido salientar que granitoides altamente evoluídos, a exemplo do PFU, que exibem características geoquímicas com granitos anorogênicos não sejam necessariamente verdadeiros granitos tipo A, pois minerais como faialita e hedenbergita sódica, que tipificam os clássicos granitos desta classe, estejam ausentes. As evidencias de saturação em fase fluida durante a sua cristalização, que contrasta com o caráter relativamente anidro dos granitoides anorogênicos, sua natureza altamente evoluída e a assimilação de componentes crustais, poderia ter contribuído no enriquecimento em HFSE e LILE e, portanto, deslocar o conjunto de amostras da suíte para o campo dos granitoides intraplaca. Logo, cautela deve ser tomada ao se utilizar diagramas de discriminação tectônica propostos por Pearce et al. (1984), pois eles caracterizam o ambiente tectôno-magmático onde o protólito granítico se originou e não necessariamente o ambiente no qual ocorreu o alojamento do magma. Desta forma, o comportamento dos elementos-traço em séries graníticas está diretamente relacionado ao protólito e eventos envolvidos durante a evolução do magma (Christiansen \& Keith 1996, Yang et al. 2003).

Contudo, essa hipótese é afastada por duas razões: (a) granitos do tipo A correspondem a séries alcalinas altamente evoluídas e fracionadas $(>70 \%$ de $\mathrm{SiO}_{2}$ ), tal como o PFU e; (b) a pequena dispersão nos valores de geoquímica indica variações decorrentes da cristalização fracionada de uma fonte homogênea e não de concentração residual de determinados elementos em função do aumento da sílica. Em adicional, o PFU exibe as características que segundo Barbarin (1999) e Nardi \& Bitencourt (2009) apontam como as mais importantes na individualização de granitos do tipo A, as quais incluem: (1) as elevadas concentrações de sílica $\left(<76 \%\right.$ ); (2) $\mathrm{K}_{2} \mathrm{O}(<5 \%)$; (3) $\mathrm{K}_{2} \mathrm{O}+\mathrm{Na}_{2} \mathrm{O}(8,4-$ $8,5 \%) ;(4)$ as razões $(\mathrm{Ga} / \mathrm{Al}) * 10^{4}$ superiores a 2,$9 ;(5)$ de $\mathrm{FeO}^{\mathrm{t}} /\left(\mathrm{FeO}^{\mathrm{t}}+\mathrm{MgO}\right)$ próximas a $0,9(0,87-0,94)$ e $(6)$ razões molares de $\left(\mathrm{Na}_{2} \mathrm{O}+\mathrm{K}_{2} \mathrm{O}\right) /\left(\mathrm{Al}_{2} \mathrm{O}_{3}\right)$ que variam de 0,92-0,96 (próximas a 1). Logo, sugere-se neste trabalho que as rochas subvulcânicas denominadas de PFU correspondam a granitos do tipo A de ambiente pós-colisional com fonte crustal e/ou relacionada a ambiente de subducção (grupo $A_{2}$ de Eby 1992). Embora estudos geocronológicos ainda não estejam disponíveis para o PFU, suas características petrográficas e litogeoquímicas permitem correlacioná-lo às ocorrências micrograníticas e granofíricas da Suíte Intrusiva Teles Pires, que segundo Souza et al. (2005) e Silva \& Abram (2008) representa um magmatismo eminentemente cálcio-alcalino, de alto $\mathrm{K}$, peraluminoso e com forte afinidade com granitos do tipo A.

As mineralizações auríferas associadas a metais de base da porção leste da PAAF exibem íntima relação espacial e genética com o PFU. Essas relações, segundo Assis (2011), atestam que o alojamento do granito subvulcânico, em nível crustal raso, teria correspondido ao evento magmático-hidrotermal responsável pela gênese destas mineralizações, a exemplo do Depósito do Francisco. Entretanto, a Suíte Intrusiva Teles Pires é regionalmente conhecida na PAAF por não hospedar mineralizações auríferas (Moreton \& Martins 2005, Souza et al. 2005, Paes de Barros 2007, Silva \& Abram 2008), ao ponto que Paes de Barros (2007) a define como o marco final do evento metalogenético na província. Contudo, os dados aqui apresentados permitem 
propor que a Suíte Teles Pires possa ter potencial para hospedar e/ou participar de processos formadores de mineralizações auríferas associadas a metais de base, especialmente para as suas ocorrências subvulcânicas pós-colisionais, a exemplo do Pórfiro União do Norte.

Os dados geoquímicos, especialmente aqueles relacionados aos diagramas de Harker, indicam sobreposição das concentrações dos elementos das SGN e SGR, indicativas, portanto, de cogeneticidade entre ambas. Em contrapartida, o distinto padrão de distribuição dos elementos maiores e traço entre o PFU e as demais suítes plutônicas, sugere que a unidade subvulcânica não seja cogenética às demais. $\mathrm{O}$ conjunto de dados litogeoquímicos para as suítes plutônicas-vulcânicas também indica um trend evolutivo do ambiente geodinâmico, desde o alojamento de magmas mais primitivos e hidratados, representados pela SGN (Suíte Intrusiva Matupá - $1872 \pm 12$ Ma; Moura 1998), gerada em arcabouço de arcos vulcânicos (granitos tipo I). O evento magmático posterior, e cogenético, corresponde a colocação de rochas mais evoluídas e com maior interação com componentes crustais, representadas pela SGR, em ambiente de arcos vulcânicos evoluindo para um arcabouço colisional. $\mathrm{O}$ encerramento do evento orogenético, portanto, teria ocorrido em plataforma mais estável, com a colocação de rochas alcalinas ácidas fortemente evoluídas, a exemplo do PFU (Suíte Intrusiva Teles Pires $-1872 \pm 17 \mathrm{Ma}$ a $1757 \pm 16 \mathrm{Ma}$; Santos 2000, Silva \& Abram 2008).

As vulcânicas de composição básica a ácida, que ocorrem em diques, representam um vulcanismo cálcio-alcalino, meta- a peraluminoso e de médio a alto $\mathrm{K}$. $\mathrm{O}$ padrão de distribuição dos elementos-traço e ETR, com anomalias negativas de $\mathrm{K}$, Th, $\mathrm{Nb}, \mathrm{Pb}$, $\mathrm{Ti}$ e $\mathrm{Eu}(\mathrm{Eu} /$ $\left.\mathrm{Eu}^{*} \approx 0,64-1,09\right)$ e razões $(\mathrm{La} / \mathrm{Lu})_{\mathrm{N}}$ compreendidas entre 6,59-12,8, mostram-se correlacionáveis aos dados geoquímicos obtidos para as SGN e SGR. Os diagramas de discriminação tectônica mostram forte afinidade com vulcânicas geradas em ambiente de arcos vulcânicos continentais, possivelmente do tipo andino. Essas vulcânicas são fortemente correlacionáveis àquelas que afloram nos arredores do Depósito aurífero do Pé Quente, estudados por Assis (2011), e representados por diabásios e basaltos traquíticos, toleiíticos a cálcio-alcalinos, de médio a alto K, fraca a moderadamente fracionados.

Finalmente, a unidade siliciclástica de cobertura é correlata à Formação Dardanelos (Grupo Caiabis) que, segundo Souza et al. (2005), representaria uma bacia formada mediante um sistema de rios entrelaçados.

CONCLUSÕES O arcabouço geológico da região de União do Norte, porção sudeste da PAAF, consiste de uma Unidade Vulcanoclástica de origem epiclástica onde estão intrudidas três suítes plutônicas: SGN, SGR e PFU. Os dados petrográficos e geoquímicos obtidos para as SGN e SGR permitem concluir sua cogeneticidade, evolução por cristalização fracionada e forte afinidade com os granitos oxidados do tipo I, enquanto que o PFU, não cogenético, com assimilação de componentes crustais e intrusivo em todas as demais unidades, representa uma suíte magmática expandida e fortemente evoluída, semelhante aos granitos do tipo A. Embora dados geocronológicos não estejam disponíveis, as SGN e SGR são, neste trabalho, tentativamente correlacionadas à Suíte Intrusiva Matupá (1872 $\pm 12 \mathrm{Ma}$ ), ao passo que o quartzo-feldspato pórfiro estaria relacionado as manifestações epizonais da Suíte Intrusiva Teles Pires (1872 \pm 17 Ma a 1757 $\pm 16 \mathrm{Ma})$.

As unidades plutônicas-vulcânicas, exceto pelo PFU, expressam um magmatismo cálcio-alcalino, magnesiano a ferroso, metaluminoso e subordinadamente peraluminoso de alto potássio, enquanto que o quartzo-feldspato pórfiro representa um magmatismo alcalino ácido, meta- a peraluminoso, ferroso e fortemente evoluído. A dispersão dos dados de elementos-traço para essas unidades representam um contínuo evolutivo, com a evolução do ambiente geodinâmico. As rochas granodioríticas teriam sido geradas em ambiente de arco vulcânico, enquanto que o PFU representaria um estágio mais tardio (pós-colisional) do evento orogenético, com maior interação de componentes crustais. No quadro metalogenético regional, a relação espacial e genética do PFU com as mineralizações auríferas associadas a metais de base, atesta o potencial metalogenético das rochas da Suíte Teles Pires, mesmo que restrito às suas manifestações epizonais.

Os diques de vulcânicas máficas a félsicas, que truncam todas as unidades plutônicas, são de difícil inserção regional e representam um vulcanismo cálcio-alcalino, meta- a peraluminoso e de médio a alto $\mathrm{K}$, coerente com aquele observado para as suítes granodiorítica e granítica. Entretanto, correspondem a rochas cogenéticas com as vulcânicas descritas por Assis (2011) nas imediações do Depósito do Pé Quente, as quais exibem assinatura cálcio-alcalina a toleítica. Recobrindo todas essas unidades ainda ocorrem as rochas sedimentares siliciclásticas da Formação Dardanelos (Grupo Caiabis).

Agradecimentos A todo o apoio logístico oferecido pela METAMAT nas atividades de campo. À FAPESP (Processos 2003/09584-3, 2003/09916-6; 2009/04438-5), CNPq/MCT (Processo 475152/03-4) e Instituto Nacional de Ciência e Tecnologia de Geociências da Amazônia (GEOCIAM) pelos auxílios à pesquisa concedidos. 


\section{Referências}

Assis R.R. 2008. Contexto geológico e associação paragenética das mineralizações auríferas de União do Norte, região de Peixoto de Azevedo, Província de Alta Floresta (MT). Trabalho de Conclusão de Curso, Instituto de Geociências, Universidade Estadual de Campinas, Campinas, 81 p.

Assis R.R. 2011. Depósitos auríferos associados a rochas graníticas da Província de Alta Floresta (MT), Cráton Amazônico: tipologia das mineralizações, modelos genéticos e implicações prospectivas. Dissertação de Mestrado, Instituto de Geociências, Universidade Estadual de Campinas, Campinas, $452 \mathrm{p}$.

Barbarin B. 1999. A review of the relationships between granitoid types, their origins and their geodynamic environments. Lithos, 46:605-626.

Bhatia M.R. \& Crook K.A.W. 1986. Trace element characteristics of graywackes and tectonic discrimination of sedimentary basins. Contributions to Mineralogy and Petrology, 92(2):181-193.

Cabanis B. \& Lecolle M. 1989. LE diagrame La/10-Y/15-Nb/8: un outil pour la discrimination des series volcaniques et la mise en evidence des processys de melange et/ou de contamination crustale. Comptes Rendus de l'Académie des Sciences - Serie II, 309:2023-2029.

Candela P.A. 1997. A review of shallow, ore-related granites: textures, volatiles, and metals. Journal of Petrology, 38(12):1619-1633.

Chandrasekharam D., Santo A.P., Capaccioni B., Vaselli O., Alam M.A., Manetti P., Tassi F. 2009. Volcanological and petrological evolution of Barren Island (Andaman Sea, Indian Ocean). Journal of Asian Earth Sciences, 35:469-487.

ChristiansenE.H. \& Keith J.D. 1996. Trace-element systematics in silicic magmas: a metallogenic perspective. In: Wyman D.A. (ed.) Trace-element geochemistry of volcanic rocks: Applications for massive sulfide exploration. Winnipeg, Geological Association of Canada, p. 115-151.

Deer W.A., Howie R.A., Zussman J. 2000. Minerais constituintes das rochas: Uma introdução. 2.ed. Lisboa, Fundação Calouste Gulbenkian, 727 p.

Eby G.N. 1992. Chemical subdivision of the A-type granitoids: Petrogenetic and tectonic implications. Geology, 20:641-644.

Floyd P.A. \& Leveridge B.E. 1987. Tectonic environment of the Devonian Gramscatho Basin South Cornwall: framework mode and geochemical evidence from turbiditic sandstones. J. Geol. Soc. London, 144:531-542.

Frost R.B., Barnes C.G., Collins W.J., Arculus R.J., Ellis D.J., Frost C.D. 2001. A geochemical classification for granitic rocks. Journal of Petrology, 42:2033-2048.

Irvine T.N. \& Baragar W.R.A. 1971. A guide to the chemical classification of the common volcanic rocks. Can. J. Earth Sci., 8:523-546.

JICA/MMAJ - Japan International Cooperation Agency/ Metal Mining Agency of Japan. 2000. Report on the Mineral Exploration in the Alta Floresta Area, Brazil. Tokyo, JICA/MMAJ, Relatório final, 137 p.

Kroomemberg S.B. 1994. Effects of provenance, sorting and weathering on ghe geochemistry of fluvial sands from different tectonic and climatic environments. In: VSP, International Geological Congress, 29, Anais, p. 69-81.

Le Bas M.J., Le Maitre R.W., Streckeisen A., Zanettin B. 1986. A chemical classification of volcanic rocks based on the total alkali-silica diagram. Journal of Petrology, 27:745-750.

Le Maitre R.W., Bateman P., Dudek A., Keller J., Lameyre J., Le Bas M.J., Sabine P.A., Schmid R., Sorensen H., Streckeisen A., Woolley A.R., Zanettin B. 1989. A Classification of Igneous Rocks and Glossary of terms: Recommendations of the International Union of Geological Sciences Subcommission on the Systematics of Igneous Rocks. Oxford, Blackwell Scientific Publications, 193 p.

Leite J.A.D. \& Saes G.S. 2003. Geocronologia $\mathrm{Pb} / \mathrm{Pb}$ de zircões detríticos e análise estratigráfica das coberturas sedimentares proterozóicas do Sudoeste do Cráton Amazônico. Geologia USP. Série Científica, 3(1):113-127.

Maniar P.D., Poccoli P.M. 1989. Tectonic discrimination of granitoids. Geol. Soc. Am. Bull, 101(5):635-643.

McDonough W.F. \& Sun, S.S. 1995. The composition of the Earth. Chemical Geology, 120:223-253.

Moreton L.C. \& Martins E.G. (orgs.) 2005. Geologia e Recursos Minerais de Alta Floresta - Vila Guarita Escala 1:250.000. Brasília, CPRM, 68 p.

Moura M.A. 1998. O Maciço Granítico Matupá e o Depósito de Ouro Serrinha (MT): Petrologia, Alteração Hidrotermal e Metalogenia. Tese de Doutorado, Instituto de Geociências, Universidade de Brasília, Brasília, 238 p.

Moura M.A. \& Botelho N.F. 1992. Petrologia do magmatismo associado à mineralização do tipo ouro pórfiro a província aurífera Juruena -Teles Pires (MT). Revista Brasileira de Geociências, 32(3): 377-386.

Moura M.A., Botelho N.F., Olívio G.R., Kyser T.K. 2006. Granite-related Paleoproterozoic, Serrinha gold deposit, Southern Amazonia, Brazil: hydrothermal alteration, fluid inclusion and stable isotope constraints on genesis and evolution. Economic Geology, 101:585-605.

Nardi L.S.V \& Bitencourt M.D. 2009. A-type granitic rocks in post-collisional settings in southernmost Brazil: their classification and relationship with tectonic and magmatic series. The Canadian Mineralogist, 46:1493-1503.

Nichols G. 1999. Sedimentology and stratigraphy. Oxford, Blackwell Science, 355p.

Paes de Barros A.J. 2007. Granitos da região de Peixoto de Azevedo - Novo Mundo e mineralizações auríferas relacionadas - Província Aurífera Alta Floresta (MT). Tese de Doutorado, Instituto de Geociências, Universidade Estadual de Campinas, Campinas, 154 p.

Pearce J.A. 1996. Sources and setting of granitic rocks. Episodes, 19(4):120-125.

Pearce J.A., Harris N.B.W., Tindle A.G. 1984. Trace element discrimination diagrams for the tectonic interpretation of granitic rocks. Journal of Petrol., 25:956-983.

Pimentel M.M. 2001. Resultados geocronológicos do Projeto Promin Alta Floresta. Brasília, UnB, Relatório Interno.

Pinho M.A.S., Schmus W.R., Chemale Jr. F. 2001. Nd isotopic composition, $\mathrm{U}-\mathrm{Pb}$ age and geochemisty of 
paleoproterozoic magmatism of the Southwestern Amazonian Craton - Mato Grosso, Brazil. In: IGc/USP, Workshop Geology of the SW Amazonian Craton: Stateof-the-art. São Paulo, Extended Abstract, p. 83-85.

Rollinson H.R. 1993. Using geochemical data: evaluation, presentation, interpretation. New York, Longman Scientific and Technical, $352 \mathrm{p}$.

Santos J.O.S. 2000. Os terrenos Paleoproterozóicos da Província do Tapajós e as mineralizações de ouro associadas. Tese de Doutorado, Universidade Federal do Rio Grande do Sul, Porto Alegre, 208 p.

Santos J.O.S., Groves D.I., Hartmann A., Moura M.A., McNaughton N.J. 2001. Gold deposits of the Tapajós and Alta Floresta domains, Tapajós-Parima orogenic belt, Amazon Craton, Brazil. Mineralium Deposita, 36:278-299.

Santos J.O.S. 2006. A compartimentação do Cráton Amazonas em províncias: avanços ocorridos no período 2000-2006. In: SBG, Simpósio de Geologia da Amazônia, 9, 1 CD-Rom.

Silva M.G. \& Abram M.B. 2008. Projeto metalogenia da Província Aurífera Juruena-Teles Pires, Mato Grosso. Goiânia, CPRM, 212 p.

Silva G.H., Leal J.W.L., Montalvão R.M.G. 1980. Projeto RADAMBRASIL - Folha SC.21 - Juruena. Rio de Janeiro, mapa geológico, escala 1:1.000.000.

Souza A.M.M.F., Landim C.A.S., Leal J.P.P., Hausen J.W.L., Neves J.E.P., João A.P., Jorge X.S. 1979. Projeto São Manue-Relatório de Progresso. Belém, DNPM/CPRM, Relatório Técnico, 46 p.

Souza J.P., Frasca A.A.S., Oliveira C.C. 2005. Geologia e Recursos Minerais da Província Mineral de Alta Floresta. Brasília, CPRM, Relatório Integrado, 164 p.

Tassinari C.C.G. \& Macambira M.J.B. 1999.
Geochronological Provinces of the Amazonian Craton. Episodes, 22(3):174-182.

Vasquez M.L. 2000. Geochronology of granitoids, mafic intrusions and mineralizations of the Tapajós Gold Province - Amazonian Craton - Brazil. In: CPRM, International Geological Congress, 31, 1 CD-Rom.

Wernick E. 2004. Rochas magmáticas: Conceitos fundamentais e classificação modal, química, termodinâmica e tectônica. Rio Claro, Editora UNESP, 655 p.

Whalen J.B., Currie K.L., Chappell B.W. 1987. A-type granites: geochemical characteristics, discrimination and petrogenesis. Contributions to Mineralogy and Petrology, 95:407-419.

Wood D.A. 1980. The implication of Th-Hf-Ta diagram to problems of tectonomagmatic classification and to stablishing the nature of crustal contamination of basaltic lavas of the British Tertiary volcanic Province. Earth and Planet Science Letters, 50:11-30.

Yang X.M., Lentz D.R., McCutcheon S.R. 2003. Petrochemical evolution of subvolcanic granitoid intrusions within the Late Devonian Mount Pleasant Caldera, southwestern New Brunswick, Canada: comparision of $\mathrm{Au}$ versus Sn-W-Mopolymetallic mineralization systems. Atlantic Geology, 39:97-121.

Yang X.M., Lentz D.R., Chi G., Thorne K.G. 2008. Geochemical characteristics of gold-related granitoids in southwestern New Brunswick, Canada. Lithos, 104:355-377.

Manuscrito ID 20806

Submetido em 17 de fevereiro de 2011 Aceito em 07 de fevereiro de 2012 